\title{
АРХЕОЛОГИЯ
}

\section{О.М. Давудов}

\section{КУРКЛИНСКИЙ МОГИЛЬНИК РАННЕГО СРЕДНЕВЕКОВЬЯ}

Курклинский могильник был обнаружен при строительстве школьной спортивной площадки на западной окраине с. Куркли Лакского района РД. Сведения о могильнике, расположенном около Курклинской сельской школы, «содержащем конские захоронения», нам сообщил доктор исторических наук, антрополог Абдурашид Гаджиевич Гаджиев.

Могильник расположен в основании горного склона, где имеются земледельческие террасы (Рис. 1; 2). При осмотре могильника, особенно на сползающем склоне земледельческой террасы, встречены отдельные трубчатые кости, фрагменты ребер, фаланги пальцев ног и рук, ключица человека.

На месте обнажения костей был заложен раскоп размером $2 \times 2$ м, ориентированный сторонами по странам света. Позже по мере необходимости этот раскоп был расширен. На гл. 1,67 м от 0 отметки находилось скопление костей коня, среди которых попадались и отдельные кости человека (Рис. 3). Рядом с ними найдены целые и обломанные железные кольца от кольчуги, фрагменты хорошо обожженной красноглиняной средневековой керамики со следами вертикального лощения (некоторые из них украшены горизонтальными прямыми и зигзагообразными резными линиями), красноглиняной тонкостенной керамики со следами ангоба густо красного цвета на наружной поверхности (обжиг плохой, тесто содержит примесь грубо истолченного песка), аспидно-серой лощеной керамики, а также небольшой обломок лепного сосуда из коричневой керамики с охристой наружной обмазкой.

Выявленные на раскопе камни и скопление костей уходили под толщу земли. Поэтому раскоп был расширен и составил $3 \times 4$ м

Последующая зачистка (гл. -167-183 м от 0), произведенная на всей площади раскопа, обнажила значительное количество хаотично расположенных костей коня и мелкого рогатого скота (баранов - овец) (Рис. 5; 6). Вместе с ними обнаружены отдельные находки железных колец от кольчуги, золотая фольга в виде умбовидной бляшки с изображением шестилепестковой розетки (Рис. 11,16) (южная прирезка, гл. $-1,70$ м), пастовые бусы, одна из которых имеет четырехгранную форму и 3 отверстия двустороннего сверления (Рис. 11,42), другая инкрустированные глазки (Рис. 11,31). Найдены также фрагменты керамики красного цвета. Отдельные из них имеют на наружной поверхности следы густо-красной краски (ангоб?), другие коричневый цвет. Явно преобладали обломки аспидно-серой лощеной керамики, часть из которых имеет следы внутренней штриховки. Несколько особняком стоят 4 обломка лощеных мисок черного цвета.

На территории основного раскопа (кв. 1-8 - на глубине -1,80 м) продолжали попадаться хаотически расположенные кости человека и животных, преимущественно лошадей. Вместе с ними найдены обломок железного гвоздя от подковы (для зимнего применения) (Рис. 11,7), железная прямоугольная пряжка (Рис. 11,14), железное шильце, каплевидная синяя стеклянная бусина (Рис. 11,40), фрагменты красноглиняной и аспидно-серой керамики.

Для выяснения полной картины ограбления к южной части западной стенки раскопа сделана прирезка размером $1,40 \times 1,50$ м, доведенная впоследствии до 1,50×3,0 м. После снятия верхнего гумусного наносного слоя глубина раскопа на месте прирезки была доведена до уровня обнаженных камней (Рис. 7). При этом какие-либо предметы материальной культуры древности или костные остатки не были обнаружены, кроме круглого известкового стержня и одного обломка аспидно-серой керамики с ручкой и одного обломка лепной толстостенной керамики с оранжевой поверхностью. Однако, при зачистке камней (кв. 11-14) найдена лобная кость человеческого черепа, трубчатые берцовые кости человека, а также кости животных, многие из которых обломаны. Здесь же выявлены черешковые железные наконечники стрел типа «площик» (Рис. 11,2) и два трехлопастных наконечника «сарматского типа» (Рис. 11,3,4), а также черешковый четырехгранный костяной наконечник стрелы (Рис. 11,5).

При последующей зачистке камней на территории восточной прирезки было выявлено погребальное сооружение - склеп (Рис. 7; 8). 
На территории остальной части раскопа (кв. 2-9) картина та же, что и описана выше: те же хаотически расположенные кости человека и животных, те же скудные находки отдельных предметов могильного инвентаря. Наиболее многочисленны остатки железной кольчуги, встречаемые в виде отдельных колец и их обломков. Встречены также два железных кольца пряжек (Рис. 10,11), одна четырехугольная бронзовая пряжка с дисковидными налепами по углам (Рис. 11,10), полая бронзовая подвеска (Рис. 11,28), а также фрагменты лепной тонкостенной аспидно-серой лощеной керамики, некоторые из которых украшены горизонтальным веревочным орнаментом (Рис. 10,9,18-20), другие - каннелюрами. Найдены и обломки красноглиняной керамики со следами густо-красной краски (ангоба) на наружной поверхности.

Как выяснилось, кости человека, животных и предметы материальной культуры на территории раскопа являются выбросом грабителей из склепа.

\section{СКЛЕП}

В юго-западном углу раскопа на гл. $-1,35$ м от 0 отметки выявлен склеп (Рис. 7; 8; 9) размером $2,10-2,15 \times 1,15-1,26$ м, ориентированный длинной осью по линии В-3 с некоторым отклонением к югу. Стенки склепа сохранились плохо, в лучшем состоянии находилась поперечная западная стена высотой 1,2 м. Она сложена из крупных продолговатых камней, уложенных ребром. Южная и северная продольные стены сохранились хуже, но, судя по остаткам, характер кладки тот же, что и у западной стены. Восточная поперечная стена представлена отрезком длиной 0,65 м, соединенным с северной стенкой связующими камнями. Пространство между южной стеной и упомянутым «отрезком» (шириной 0,6 м) представляло собой лаз в погребальную камеру. Вдоль северной стенки склепа в два ряда уложены камни, составляющие нечто подобное скамье, которые использовались грабителями, как сиденье, для тщательной зачистки и осмотра содержания погребальной камеры. Все целые и раздробленные, хаотично расположенные кости и остатки предметов материальной культуры, были выброшены из склепа и сосредоточены перед лазом.

Дно могилы находилось на глубине $-2,42$ м от 0 отметки (Рис. 9).

В склепе встречены отдельные фрагменты костей человекаили ихтлени костиживотных.

Инвентарь из склепа представлен обломком нижней части железного меча (Рис. 11,1), несколькими фрагментами серебряных поясных язычков (Рис. 11,19-24), бронзовой обоймой (Рис. $11,26)$, обломками железных изделий, возможно, пряжек (Рис. 11,12-14), бронзовой плоской «лунницей» (Рис. 11,44), обломками тонкой медной проштампованной пластинки, вероятно, служившими накладками для пояса (Рис. 11,17); бусами из пасты (Рис. 11,36), синего стекла (бисер); одной полой бронзовой подвеской (Рис. 11, 28), а также фрагментами аспидно-серой лощеной и красной глиняной (со следами густо-красной краски на наружной поверхности) керамики (Рис. 10). Некоторые из упомянутых фрагментов керамики и бусы найдены под выкладкой камней, выложенных грабителями.

Как выше отмечалось, по всей площади склепа встречались угольки. У входа в склеп (кв. 1,10-12) расчищено огромное количество хаотически расположенных костей человека, крупных и мелких рогатых животных, лошадей. Это был выброс из погребальной камеры. Вместе с ними найдены бронзовая поясная пряжка с железным язычком и круглым щитком (Рис. 11,11), прямоугольная железная пряжка (Рис. 11,14), костяной черешковый четырехгранный наконечник стрелы (Рис. 11,5), бронзовое кольцо от украшения, железные кольца от кольчуги, янтарное колечко от украшения (Рис. 11,41), стеклянная бородавчатая бусина (Рис. 11,31), бронзовая каплевидная бусина (Рис. 11,39), сердоликовая округлая бусина с двусторонним сверлением и надрезом (Рис. 11,30) у отверстия бусины, а также фрагменты небрежно вылепленной коричневой керамики из плохо перемешанного теста с примесью грубо истолченного песка (Рис. 10); аспидносерой и серой тонкостенной керамики, отдельные из которых имеют внутреннюю штриховку (а один обломок от переходной части дна к тулову кувшина имеет и наружную штриховку) или горизонтальные резные линии (Рис. 10,8-10) и красная, тонкостенная керамика из теста с примесью грубо истолченного песка с остатками густо-красной краски (ангоба) на наружной поверхности (33 обломка).

Инвентарь.

I. Керамика представлена обломками лепных, в большинстве случаев невыразительных фрагментов сосудов красного и серого цвета.

Среди серой керамики выделяется группа аспидно-серых лощеных черепков. Отдельные фрагменты имеют следы внутренней штриховки, а на двух обломках на части, переходящей от дна к тулову заметна и наружная штриховка. 
Несколько особняком стоит коричневая керамика, представленная несколькими обломками тонкостенных и толстостенных грубых сосудов, а также чернолощеная керамика, представленная четырьмя фрагментами мисок.

Красноглиняная керамика вылеплена из теста с примесью песка, как правило, плохо истолченного (обжиг слабый), а серо-глиняная, особенно аспидно-серая имеет плотный черепок и равномерный обжиг. Коричневая керамика также сделана из плохо перемешанной глины (примесь грубо истолченного песка).

Серая тонкостенная керамика:

1) Кувшин с расширяющимся к устью цилиндрическим горлом и биконическим туловом. Внутренняя поверхность сосуда заглажена пучком травы или каким-то зубчатым предметом. Наружная поверхность вылощена ( $\mathrm{d}$ дна $=102$ мм; d горла =0,56 мм) (Рис. 10,13);

2) Такой же кувшин только меньшего размера;

3) Обломок дна и стенки такого же сосуда. Внутренняя поверхность и переходная от дна к стенке часть заштрихована (Рис. 10,7);

4) Черепок из аспидно-серой керамики, украшенный вертикальным рифлением (Рис.11,18);

5) Обломок стенки сосуда с круглой в сечении ручкой кольцевидной формы (Рис.10,11);

6) Обломок горшка с пухлым венчиком (Рис. 10,4);

7) Черепок тонкостенного сосуда с веревочным орнаментом (Рис. 10,20);

8) Обломок кружки (Рис. 10,21).

Красноглиняная керамика со следами ангоба:

1) Обломок горловины кувшина со сливным носиком, по сторонам которого имеются налепы в виде семилепестковых розеток и поясом из волнистых резных линий по основанию горловины (Рис. 10, 2), поверхность шероховатая;

2) Обломки горловины кувшина со сливным носиком. На наружной поверхности имеются следы вертикального лощения. В основании горловины орнамент из горизонтальной волнистой резной линии (Рис. 10, 6);

3) Обломок горловины кувшина с ручкой круглой в сечении формы, отходящей от венчика (Рис. 10,5);

4) Обломок горловины кувшина с ручкой, соединяющей плечики со средней частью горловины (Рис. 10,1).

Красноглиняная штрихованная керамика:

1) Обломок дна и стенок кувшина (Рис. 10,7);

2) Кольцевидная ручка, круглая в сечении (Рис. 10,11).

II. Предметы вооружения:

1) Остатки кольчуги представлены железными кольцами диаметром 11 мм, сделанными из тонкой круглой в сечении проволоки;

2) Обломок нижней части клинка железного меча (Рис. 11,1). Форма не восстанавливается;

3) Железный, черешковый наконечник стрелы типа «площик» с опущенными концами, длина $=54$ мм (Рис. 11,2);

4) Обломок трехлопастного железного черешкового наконечника стрелы сарматского типа, длина сохранившейся части - 17 мм (Рис. 11,4);

5) Обломок трехлопастного железного черешкового наконечника стрелы с опущенными жалами, длина $=38$ мм (Рис. 11,3);

6) Костяной четырехгранный черешковый наконечник стрелы. Изготовлен он из трубчатой кости животного. На черешке имеются зазубрины. Общая длина - 44 мм, длина черешка - 13-15 мм (Рис. 11,6);

7) Такой же костяной наконечник стрелы. Общая длина - 31 мм, длина черешка - 21 мм (Рис. $11,5)$.

III. Предметы туалета и украшения:

1) Железная пряжка прямоугольной формы из круглой в сечении проволоки. Концы проволоки заходят друг за друга (Рис. 11,14);

2) Два обломка железной проволоки, по-видимому, от пряжки такой же формы (Рис. $11,12,13)$;

3) Обломок бронзового изделия в виде когтя хищника из круглой всечениипроволоки;

4) Несколько обломков от железного овального изделия, вероятно, пряжки. Проволока, из которой сделана она, имеет круглую в сечении форму; 
5) Обломок круглой железной пряжки, диаметром 25 мм, изготовленной из круглой в сечении проволоки (Рис. 11,8);

6) Такая же пряжка;

7) Обломок бронзовой плоской пряжки прямоугольной формы с дисковидными украшениями по углам (Рис. 11,10);

8) Бронзовая овальная пряжка с железным язычком и круглым щитком для соединения с кожаным ремнем (Рис. 11,11); $11,18)$

9) Серебряная овальная пряжка с петлей-язычком для соединения с кожаным ремнем (Рис.

10) Серебряные поясные язычки в виде узких продолговатых четырехугольных пластинок с закругленными концами - 4 экз. (Рис. 11,19-21,24);

11) Серебряные язычки прямоугольной формы от пряжек - 2 экз. (Рис. 11,22);

12) Серебряное украшение в виде топорика - 1 экз. (Рис. 11,25);

13) Бронзовое изделие в виде обоймы с остатками древесины внутри. Изделие было просверлено и обвязано тонкой бронзовой проволокой, закрученной у выхода и заканчивалось к концу под четырехугольной рамочкой (Рис. 11,26);

14) Круглая проштампованная бляшка, диаметром 22 мм, сделанная из золотой фольги с изображением шестилепестковой розетки (Рис. 11,16);

15) Полая бронзовая подвеска, составленная из двух полушарий, верхне из которых снабжено петлей для подвешивания (d - 13 мм) - 2 экз. (Рис. 11,27,28);

16) Подвеска-пронизка из просверленного зуба (Рис. 11,33);

17) Лунница, сделанная из тонкой бронзовой пластинки, с прямоугольным вырезом в верхней части для подвешивания (Рис. 11,14).

Как было отмечено выше, на глубине $-2,42$ м от 0 в основной части склепа находился материковый грунт. Однако, в северо-западном углу склепа находилось овальное коричневое пятно рыхлого насыпного грунта, уходящее под западную и северную стенки склепа (Рис. 12). Для продолжения исследования характера отмеченного «пятна» была сделана прирезка к западу и северу раскопа, размером $0,50 \times 2,0$ м. Последующая зачистка выявила пятно засыпи грунтовой могилы с захоронениями животных.

ГРУНТОВАЯ МОГИЛА С ЗАХОРОНЕНИЯМИ ЖИВОТНЫХ (Рис. 12; 14-15), овальной несколько ссуженной к западу (возможно, из-за скального выхода с северной стороны) формы, имела размеры $2,17 \times 1,10-1,60$ м и была ориентирована длинной осью по линии 3-В с легким отклонением к югу. В материк могила была впущена на 0,56 м

На западном конце могилы встречено огромное количество примеси золы и угольков (Рис. 14). В верхних слоях на краю могилы найдена серебряная деталь от украшения и бронзовая согнутая пополам пластинка.

Могила содержала 13 конских захоронений и одно захоронение крупного рогатого животного.

Захоронение № 1 (Рис. 14) находилось на гл. -2, 55 м от 0 отметки, у юго-восточной стенки могилы. От конского скелета в анатомическом порядке сохранились позвонки, лежавшие по направлению с северо-востока на юго-запад.

Захоронение № 2 (Рис. 14) находилось рядом с первым захоронением на той же глубине. От конского скелета в анатомическом порядке сохранились позвонки и отходящие от них ребра. Причем позвонки ориентированы параллельно позвонкам первого погребения.

К юго-западу от них находится конский череп, лопатка и голенная кость. Трудно установить, какому из вышеописанных скелетов коня они относятся. Судя по расположению, они одинаково могли принадлежать коню первого погребения и коню второго погребения.

Над черепом коня, в области пасти найден обломок железных удил с серебряным кольчатым псалием (Рис. 16,10).

Захоронение № 3 (Рис. 14) находилось на гл. $-2,65$ м относительно 0 отметки, около скопления золы. Конь был уложен на правом боку, головой на запад. Причем голова лежала на туловище.

Под конскими ребрами найден железный наконечник копья с граненной втулкой (Рис. 16,1). Острым концом он был обращен к спине коня.

Захоронение № 4 (Рис. 14) расположено в центре могилы и представлено согнутыми в коленях костями передних ног коня. Другие кости этого скелета не встречены.

Инвентарь также не встречен. 
В северо-восточном конце могилы на гл. $-2,57$ м от 0 отметки встречены берцовые кости крупного животного. Такие же кости встречены и около костяка погребения № 3.

После снятия костей всех вышеописанных погребений производилась последующая зачистка. При этом выявлены новые погребения животных.

Захоронение № 5 (Рис. 15A) расположено в центре погребального сооружения на гл. $-2,82$ м от 0 отметки. Животное было уложено на левый бок спиной к западу, головой на север. Кости принадлежат крупному рогатому животному.

Севернее этого скелета встречен черепок аспидно-серой керамики с внутренней штриховкой.

Захоронение № 6 (Рис. 15A) принадлежит коню, и оно находилось на гл. $-2,82$ м от 0 отметки западнее костяка погребения № 5 и, судя по расположению позвонков, ориентировано по линии запад-восток. Животное лежало на левом боку. Голова, по-видимому, была уложена на туловище.

С костями этого животного инвентарь не встречен.

Захоронение № 7 (Рис. 15A) выявлено на гл. -2,82 м от 0 отметки у северной стенки могилы, т.е. у скального выхода. От скелета коня сохранились фрагменты костей морды с передними зубами и берцовая кость.

Инвентарь не встречен.

Захоронение № 8 (Рис. 15А) расположено южнее центрального погребения (№ 5), на гл. -2,82 м от 0 отметки и представлено фрагментами костей черепа коня, позвонками и берцовой костью.

Сопутствующий инвентарь не выявлен.

Захоронение № 9 (Рис. 15А) расчищено у восточной стенки могилы, на гл. $-2,82$ м от 0 отметки. Костяк принадлежит коню. В анатомическом порядке сохранились лишь позвонки. Однако говорить конкретно что-либо о положении захороненного животного не представляется возможным.

Юго-западнее черепа выявлена бронзовая овальная пряжка небольших размеров (Рис. 16,6).

Захоронение № 10 (Рис. 15А) залегало на гл. $-2,82$ м от 0 отметки. Оно представлено тремя позвонками коня, лежащими в анатомическом порядке, и обломком ребра. Они лежали особняком у северной стенки могилы (у скального выхода).

Инвентарь отсутствует.

После снятия костей животных второго слоя произведена дальнейшая расчистка. Выявлено еще четыре погребения.

Захоронение № 11 (Рис. 15В) находилось на гл. -2,96 м от 0 в восточной части могилы. Захоронение конское. Судя по расположению костей скелета, животное было уложено на левый бок с подогнутыми ногами, головой на северо-восток. $16,3)$.

Между подогнутой ногой и ребрами найдена пластинчатая рамочная бронзовая пряжка (Рис.

Захоронение № 12 (Рис. 15Б) расположено севернее погребения № 11 на гл. -2,96 м от 0 отметки. Оно принадлежит коню. От скелета сохранились в анатомическом порядке лишь ребра. Рядом найдены трубчатые кости. Судя по положению костей, животное лежало на левом боку.

Поперек ребер прослежена линия тлена от кожаного ремня. На нем находились две маленькие и одна большая плоские рамочные бронзовые пряжки. Такой же формы две большие пряжки найдены по сторонам ребер (по одной с каждой стороны) (Рис. 16,3-5,7-8).

Захоронение № 13 (Рис. 15Б), представленное челюстью коня, несколькими трубчатыми костями и лопаткой, расположено западнее описанных погребений № 11 и 12 на гл. $-2,96$ м от 0 отметки.

На лопатке встречена рамочная бронзовая пряжка (Рис. 16,9).

Захоронение № 14 (Рис. 15Б) находится у северо-восточной стенки могилы на гл. $-2,96$ от 0 отметки и представлено несколькими позвонками, расположенными в анатомическом порядке и трубчатыми костями. Кости принадлежат коню.

Инвентарь отсутствует.

На гл. $-2,98$ от 0 отметки в могиле находился материковый грунт.

Инвентарь грунтовой могилы с конскими захоронениями:

1) Железный наконечник копья с граненой втулкой и пером в виде клинка кинжала, начинающимся прямо от ободка втулки. Длина изделия - 36 см, ширина клинка -5 см, диаметр втулки - 3, 2 см (Рис. 16,1);

2) Обломок железных удил с серебряным кольчатым псалием, снабженным двумя серебряными зажимами для соединения с ремнями. Сохранился обломок железного грызла. 
Серебряные зажимы заклепаны и имеют на лицевой стороне треугольный выступ, отходящий от кольца (Рис. 16,10);

3) Бронзовая плоская четырехугольная пряжка в виде рамочки. Вокруг прямоугольной прорези имеется выступ. По углам изделия заметны бронзовые заклепанные гвоздики. Четыре из них имеют размеры 40×42 мм, а два - 26 х 23 мм (Рис. 17,6-5,7-9);

4) Бронзовая овальнорамчатая литая пряжка с утолщением спереди. (Рис. 16,6);

5) Серебряная овальная пряжка с петлей для прикрепленияк кожаномуремню(Рис. 16,12);

6) Серебряные поясные наконечники или язычки с треугольной прорезью на одном из концов - 2 экз.; длина - 66 мм (Рис. 16,13,14);

7) Обломки от язычков пояса. Два язычка имеют заклепанные серебряные гвоздики на концах, другой - срезанный под косой угол бортик (Рис. 16,15-17);

8) Серебряная подвеска - язычок подтрапециевидной формы имеет два отверстия от гвоздей. На поверхности - украшения из выпуклого треугольника, обращенного острым углом вниз (Рис. $16,11)$;

9) Серебряное украшение в виде ромба посередине двух кругов. По центру ромба и кругов гвозди с полусферическими шляпками. Верхняя часть изделия ровная, а по краям бортика имеется полоса, срезанная под угол (Рис. 16,2);

10) Бронзовая обойма от украшения в виде согнутой пополам прямоугольной пластинки. Размер 25 х 30 мм;

11) Бусы.

На территории основного раскопа на гл. $-2,10$ м находился материковый грунт. Однако в западной части кв. 2 и 7 выявлена тонкая песчаниковая плита, после снятия которой обнажилось темное пятно засыпи могильной ямы (Рис. 12). Причем, это пятно уходило к западу под толщу стенки раскопа. Была сделана прирезка размером $1 \times 2$ м на гл. $-2,30$ м была обнаружена грунтовая могила с женским захоронением

ГРУНТОВАЯ МОГИЛА С ЖЕНСКИМ ЗАХОРОНЕНИЕМ (РИс. 12) чеТЫрехуГОЛЬНОЙ В плане формы (к изголовью несколько расширяется) размером 2,15×0,56-0,75 м была ориентирована по линии юго-запад-запад-северо-восток-восток. Судя по упомянутой плите, могила перекрывалась песчаниковыми плитами. Могила была врезана в материк на 0,38 м. Повидимому, надмогильным знаком погребения служила узкая толстая песчаниковая плита, выявленная у изголовья погребения.

От человеческого скелета сохранился лишь тлен. Однако, в юго-западном-западном конце могилы найдены зубы человека, а на северо-восточном-восточном конце - фаланги пальцев ног. Ближе к середине могилы сохранилась лучевая кость руки. В целом, покойник был захоронен вытянуто на спине головой на юго-запад-запад, ногами на северо-восток-восток.

У изголовья могилы с левой стороны погребенного стоял красноглиняный кувшин (Рис. 13,2), a c правой стороны - красноглиняный горшок (Рис. 13,1). Около кувшина найдена полая бронзовая подвеска (Рис. 13,5), зеркало из белого сплава (Рис. 13,7). Чуть ниже найдены железный черешковый трехлопастный наконечник стрелы (Рис. 13,9), бронзовые браслеты с утолщениями на концах и в середине (Рис. 13,10,11), обломанные железный стержень (Рис. 13,8) и нож с черенком и прямой спинкой (Рис. 13,6), а также бронзовая застежка (Рис. 13,4).

Выше горшка найдено костяное пряслице (Рис. 13,3), ниже - скопление большого количества бус. Причем, часть бус встречается и в центре могилы (Рис. 12).

Инвентарь грунтовой могилы:

1) Красноглиняный лепной кувшин с боченковидным туловом, широким устойчивым дном, горловиной, расширяющейся к устью и округлой в сечении ручкой, соединяющей основание устья с плечиками. Обжиг неравномерный (в одном месте пережжен и имеет серый цвет). Тесто содержит примесь битой керамики. Наружная поверхность заглажена, по-видимому, после сушки (h кувшина - 15,2 см; d венчика - 9 см; d горловины - 8,4 см; d дна - 9,5 см) (Рис. 13, 2);

2) Красноглиняный лепной горшок с прямым, переходящим в срезанный венчик горлом и вздутым, расширяющимся к широкому дну туловом. Техника производства сосуда та же, что и у кувшина (h сосуда - 9,5 см; d горла - 8,5 см; d дна - 11 см) (Рис. 13,1);

3) Бронзовая полая подвеска (бубенчик), сделанная из двух полушарий, верхнее - снабжено петлей для подвешивания, а нижнее - крестовидной прорезью. Изделие содержит внутри цельнолитой бронзовый шарик (d изделия - 24 мм; h вместе с петлей - 29 мм) (Рис. 13,5);

4) Зеркало из сплава белого цвета (биллон) с петлей для подвешивания на обороте, вокруг которых изображены идущие по кругу рептилии похожие на скорпионов. От центра (петли) 
радиально отходят две линии, опирающиеся о внешний валик с насечками. Предмет отлит по восковой модели (d-84 мм) (Рис. 13, 7);

5) Железный, черешковый трехлопастной наконечник стрелы. Общая длина - 66 мм, длина черешка - 21 мм (Рис. 13,9);

6) Бронзовые браслеты с утолщениями на концах и в середине сделаны из тонкой согнутой в прямой угол пластинки. На одном из них (меньшем) встречены отпечатки материи - сукна (Рис. $13,10,11)$

7) Железный стержень из круглой в сечении проволоки. Сохранившаяся длина 120 мм (Рис. $13,8)$;

8) Железный черешковый нож с прямой спинкой. Конец обломан. Общая длина сохранившейся части - 98 мм, длина черенка - 36 мм. На черешке и клинке сохранились следы от деревянных ножен и ручки (Рис. 11,6);

9) Бронзовая застежка. Изделие представляет собой круглый в сечении бронзовый стержень с перехватом в середине и кубическими навершиями со срезанными углами на концах. Части стержня между навершиями и перехватом имеют форму вытянутых усеченных пирамид, обращенных узкими концами наружу. Длина изделия -39 мм (Рис. 13,4);

10) Костяное пряслице, выполненное из коленной чаши животного (d - 40 мм, d отверстия 10 мM);

11) Разнообразные по форме бусы из стекла, пасты, сердолика,горногохрусталя иянтаря.

На глубине -2,68 м по территории всего раскопа обнажился материковый грунт.

Характер погребальных сооружений и погребального инвентаря Курклинского могильника позволяет поставить его в один ряд с такими памятниками Дагестана как Карабудахкентский могильник № 3 (II-III вв.), Большой Буйнакский курган (III-V вв.), Верхнечирюртовский грунтовый могильник (V-VII вв.), нижний слой Галлинского могильника, Тидибский, Ураллинский, Килятлинский, Миатлинский, Чадаколобский, Ансалтинский, Годоберинский, Талойлогский, Согратлинский и др. могильниками V-VII вв. (Атаев Д.M, 1961. С. 24, 25-29; Путнцева Н.Д., 1961. С. 248-264; Смирнов К.Ф., 1961. С. 208-219; Zakharov A.A., 1931. Р. 183 и сл.). На Курклинском могильнике обнаружены одна овальная грунтовая могила с захоронениями животных (13 коней и одного крупного рогатого животного) и грунтовая могила четырехугольной формы, перекрытая песчаниковой плитой с вытянутым на спине женским захоронением, ориентированным головой на юго-запад-запад, а также четырехугольный склеп с лазом в восточной торцовой стене, а также своеобразный инвентарь, представленный керамикой, орудиями труда, предметами вооружения, украшениями и туалетными принадлежностями.

Могильник занимает своеобразную нишу в археологической историко-культурной системе раннесредневекового Дагестана. Он имеет местные корни. В тоже время могильник отражает характер культурно-исторических связей раннесредневекового населения долины Казикумухского койсу с населением Юго-Восточной Европы и Северного Кавказа.

Обряд погребения коней или их частей в Дагестане появляется в скифское время и с этого времени практиковался здесь до средневековья. Овальная грунтовая могила с конскими коллективными захоронениями была обнаружена на Сумбатлинском могильнике рядом с каменным ящиком, содержащим парное погребение. Правда, там количество коней было меньше и вместе с конями была захоронена собака (Давудов, 1977. С. 113, 127-128). Но по характеру инвентаря, массовым захоронениям коней и всадников Курклинский могильник напоминает могильники эпохи Великого переселения народов, особенно могильник на р. Дюрсо близ Новороссийска (Дмитриев А.В., 1979.С. 52-57; 1979а. С.212-229).

Грунтовые могилы с человеческими захоронениями встречены в Дагестане, начиная со скифского времени. На раннесредневековых памятниках они зафиксированы на Урадинском, Галлинском (нижние слои) и Ураллинском могильниках (Атаев Д.М, 1963. С. 44 45). В верхних раннесредневековых слоях сопредельного Сумбатлинского могильника обнаружены не грунтовые могилы, а каменные ящики (Давудов O.M., 1977), что указывает, что грунтовая могила на Курклинском могильнике является пережиточным явлением.

Курклинский склеп четырехугольной в плане формы находит аналогии в Дагестане на Сумбатлинском могильнике, а также на могильниках V-XII в., расположенных около сс. Муги, Дегва, Верхний Каранай, Гапшима, Дуранги, Аркас и др. (Давудов О.М, 1996. С.80-81)

Зафиксированный в грунтовой могиле обряд вытянутого на спине положения также является характерным для раннесредневекового Дагестана (Атаев Д.М, 1963. С. 48; Абрамова М.П., 1977. C. 67). 
Среди керамических изделий могильника серая лощеная, тонкостенная керамика составляет значительную долю. Она представлена обломками кувшинов с расширяющимся к устью горлом и биконическим туловом (Рис. 10,13), черепками аспидно-серой керамики, украшенными вертикальным рифлением (Рис. 10,18), аналогичными горшкам из Карабудахкентского могильника № 3 (Смирнов К.Ф., 1961. С. 213. Рис. 38, № 112.), а также кувшинам из аланских памятников Северного Кавказа V-XII вв. н.э. (Кузнецов В.А., 1962. Рис. 3-а. 9; 15-a, 1, 8; 24-a, 1, 5).

Среди красноглиняной керамики выявлены обломки кувшина со сливным носиком, по сторонам которого имеются налепы в виде семилепестковых розеток и пояс из волнистых резных линий по основанию горловины (Рис. 10,2), поверхность шероховатая. Обнаружены также обломки горловины кувшина со сливным носиком, на наружной поверхности которой имеются следы вертикального лощения. В основании горловины - орнамент из горизонтальной волнистой резной линии (Рис. 10,6).

Встречены и целые сосуды (красноглиняный лепной кувшин и красноглиняный лепной горшок), характерные для раннесредневековых памятников Дагестана, а также обломки красноглиняных заштрихованных сосудов: дна и стенок кувшина (Рис. 10,7,8), кольцевидная ручка круглой в сечении формы (Рис. 10,17). Все они находят аналогии на раннесредневековых памятниках Дагестана.

Орудия труда представлены костяным пряслицем из просверленной коленной чаши животного и железным черешковым ножом с прямой спинкой (Рис. 11,3,6).

Предметы вооружения представлены железным наконечником копья с граненой втулкой и кинжаловидным пером (Рис. 17,1). Аналогии этому наконечнику копья нам не известны. Но более популярны наконечники стрел. Все найденные здесь железные наконечники характерны для памятников более раннего времени и пережиточно сохранились на Курклинском могильнике. Так железный черешковый наконечник стрелы типа «площик» с опущенными концами (Рис. 11,2) характерен для эпохи поздней бронзы - раннего железа. Железные черешковые трехлопастные наконечники стрел с опущенными жалами, размером 66 мм (длина черешка - 21 мм. Рис. 13,6), характерны для Северного Кавказа позднесарматского времени. C IV-V вв. на смену этим наконечникам появляются трехлопастные черешковые наконечники стрел, но с уступами у основания черешка. Крупные черешковые трехлопастные железные наконечники стрел, генетически связанные с такими же, но более мелкими стрелами сарматов, встречаются в памятниках Дагестана V-VII вв. (Тидибский, Гапшиминский, Карабудахкентский № 3 (II-III вв.) могильники (Атаев Д.М, 1963. С. 71. Рис. 5, 11; Смирнов К.Ф., 1962. С. 213. Рис. 38, № 54, 94; С. 215. Рис. 39, № 126), в погребениях Большого Буйнакского кургана (Абрамова М.П., 1980. С.129; Рис. III,36; V, 24.) и других памятниках Дагестана албанского и раннесредневекового времени (Давудов О.М., 1996. С. 128-129). Один аналогичный курклински наконечникам трехлопастный наконечник стрелы найден в культовом месте Арчо вместе со статуэтками воинов позднесасанидского времени (Круглов А.П., 1946. Рис. 11,6).

На Курклинском могильнике обнаружены два экземпляра костяных четырехгранных черешковых наконечников стрел, изготовленных из трубчатой кости животного(Рис. 11,5,6).

Особенно примечательны остатки кольчуги, представленные железными кольцами диаметром 11 мм, сделанными из тонкой круглой в сечении проволоки.

Среди туалетных принадлежностей выделяются два бронзовых браслета с утолщениями на концах и посередине, сделанные из тонкой согнутой в прямой угол пластинки (Рис. 13,10,11). Браслеты с тремя утолщениями характерны для памятников Дагестана (Д.М Атаев насчитал 31 эк3.- Котович В.Г., Мунчаев Р.М, Путинщева Н.Д., 1961. С. 256. Рис. 4,2,4; С. 278; Путинцева Н.Д., 1961. С. 256. Рис. 7,7; Атаев Д.М, 1961. С. 243. Рис. 25,1; С. 58. Рис. 5,7) и Горной Чечни (Багаев $M X$., 2008. С. 143. Рис. 228, 3). Наиболее близки нашим браслетам формы браслетов, обнаруженных вблизи с. Верхний Каранай (Исаков МИ., 1966. С. 5. Табл. 10, 2) и браслет из публикации Д.М Атаева без указания места находки (Атаев Д.М, 1963. С. 57-60. Рис. 5, 7). Некоторые исследователи полагают, что они появились в Дагестане в албанское время и получили широкое распространение в раннем средневековье (Котович В.Г., Мунчаев Р.М, Путинцева Н.Д., 1961. С. 256). Более уточненной представляется их дата V-VII вв., хотя в Дагестане браслеты с утолщением на концах и в середине встречаются и позже. Так, на Агачкалинском могильнике VIII-XІвв. встречен массивный браслет, близкий курклинским. Аналогичные предметы найдены в катакомбах VII-VIII вв. близ Кисловодска (Рунич А.П., 1968. № 3. С. 212. Рис. 4,1), в Чмийских катакомбах VIII-IX вв. и т.д. (Багаев МX., 2008.С. 143. Рис. 228,3;229,3;230,2). 
Особый интерес представляет зеркало из сплава белого цвета (биллон) с петлей для подвешивания на обратной стороне, вокруг которого изображены ползущие по кругу друг за другом рептилии, похожие на скорпионов (Рис. 13, 7). Аналогичные зеркала с теми же изображениями на обороте происходят из нижнего слоя Галлинского могильника (Котович В.Г., 1961. С. 47. Рис. 28,3), из окрестностей с. Хунзах, из Дурангинских склепов и Агачкалинского могильника (Смирнов К.Ф., 1952. Рис. 39, 8). Они отнесены к V-VII вв. (Атаев Д.М, 1963. С. $68-$ 69.).

Бронзовая застежка, названная Н.Д. Путинцевой подвеской («пуговицей») (Рис. 13,4), находит аналогии на Верхнечирюртовском грунтовом могильнике V - VII вв. (мог. 40) (Путинщева Н.Д., 1961. С. 257. Рис. 9, 4). Этот могильник А.К. Амброз датирует концом VII первой половиной VIII в. (Амброз А.К., 2008. С. 128), Гуни (Багаев МХ., 2008. С. 142; см. также: Дмитриев А.В., 1981. Табл. 88, 48, 49). Аналогичные застежки происходят из памятников Северного Кавказа VII - VIII вв. (Саханев В.В., 1914. Рис. 22, 10; Рунич А.П., 1968. № 3. Рис. 4, 11). М.X. Багаев датирует их V-VIII вв., оговорившись, что они встречаются и в более поздних памятниках степной территории (Багаев МX., 2008. С.142. Рис. 224, 54).

Среди наших находок наиболее многочисленны пряжки, изготовленные из железа, бронзы и серебра. Железные пряжки представлены прямоугольными (Рис. 11, 12, 13, 14), овальными (Рис. $11,13$ ) и круглыми формами (Рис. 11,10$)$. Они плохо сохранились, и судить о них сложно.

Бронзовые пряжки выразительны и сохранились лучше. Одна представлена круглорамчатой литой формой, передняя часть рамки которой толще, задняя часть тоньше. У нее нет щитка (Рис. 16,6). Эта пряжка относится ко второму варианту первого типа первого отдела по классификации В.Б. Ковалевской и датируется временем от III до VII в. (Ковалевская В.Б., 1979. С. 15).

Другая бронзовая круглорамчатая пряжка с круглым щитком для соединения с кожаным ремнем (Рис. 11,11) относится ко второму типу первого отдела по классификации В.Б. Ковалевской и датируется IV-V вв. (Ковалевская В.Б., 1979. С. 15).

Серебряные мелкие круглорамчатые пряжки с петлевидным щитком для прикрепления к кожаному ремню и без язычка представлены двумя экземплярами (Рис. 11,18; 16,12).

Бронзовые плоские прямоугольнорамчатые бесщитковые пряжки представлены семью экземплярами, шестью целыми и одной сломанной (Рис. 16,3-5,7-9). Точных аналогий этим пряжкам мы не знаем В.Б. Ковалевская относит прямоугольнорамчатые пряжки ко второму варианту первого типа шестого отдела пряжек своей классификации и суммарно датирует V-VII вв. (Ковалевская В.Б., 1979. С. 44).

Обломок железных удил с серебряным кольчатым псалием, снабженным двумя серебряными зажимами для соединения с ремнями (Рис. 16,10). Аналогичные удила характерны для обширной территории юго-восточной Европы гуннского времени. В. Шкорпил датировал их III в. Однако такие вещи известны и в более позднее время, доживая вплоть до $\mathrm{V}$ в. на территории Восточной и Центральной Европы (Шкорпил В., 1910. С. 33-34, Рис. 15; Кузнещов В.А., 1962. С. 16. Рис. 4,1). Более точную дату дают удила из Керченского склепа конца IV - первой половины V вв. (Засеикая И.П., 1994. С. 41; 1979. С. 10. Рис. 5,1,2,4, 5, 15-17; Спищын А.А., 1905. С. 120. Рис. 3639; Шкорпил В.В., 1907. С. 1-66).

Среди находок из Курклинского могильника имеются бронзовые полые подвески (бубенчики - 2 экз.) (Рис. 11,27,28), серебряные поясные язычки (Рис. 11,19-24; 16,13-16), серебряные язычки прямоугольной формы от пряжек (2 экз.) (Рис. 11,17), серебряное украшение в виде топорика (1 экз. - Рис. 11,25), бронзовая обойма (Рис. 11,26) и круглая проштампованная бляшка диаметром 22 мм из золотой фольги с изображением шестилепестковой розетки (Рис. 11,16). Но наибольший интерес представляет трехрогая, пельтовидная лунница, изготовленная из тонкой бронзовой пластинки, с прямоугольной прорезью для петли в верхней части (Рис. 11,44). В российской археологической литературе распространена точка зрения о западном происхождении аналогичных лунниц (Кропоткин В.В., 1978. С. 162; Каргапольцев С.Ю., Бажан И.А., 1993. С. 113-120). М.П. Абрамова утверждает, что подобные лунницы не получили распространения на территории Северного Кавказа и прилегающих степных районов (Абрамова М.П., 1998. С. 61-67). Мне, помимо нашей находки на Курклинском могильнике, известны еще две находки трехрогих лунниц - на могильнике Верхняя Рутха (Северная Осетия) (Уварова П.С., 1900. С.237. Табл. СІ, 3,4). Этот могильник относится к V в. (Амброз А.К., 1989. С. 41). С.Ю. Каргапольцев и И.А. Бажан полагают, что в IV в. в Европе бытуют, в основном, гладкие и штампованные трехрогие лунницы, а в V в. отмечается использование полихромных изделий (Каргапольцев С.Ю., Бажан И.А., 1993. C. 115-118). С учетом значительного расстояния между Европой и Дагестаном, вероятно, 
правомочно относить курклинскую лунницу не к IV в., а к тому же времени, что и лунница из Верхней Рутхи - к Vв.

Стратиграфические наблюдения за характером могильных комплексов позволяют наметить следующий порядок их расположения по горизонтам. Выше всех сооружений залегал разграбленный склеп, который перекрывал грунтовую могилу с захоронениями животных. Отсюда и относительная дата наших комплексов: самым поздним сооружением является склеп. Ему предшествует грунтовая могила с захоронениями животных. Хронология грунтовой могилы с женским захоронением требует особого обоснования.

Как выше отмечалось, склеп содержал наиболее архаичные предметы: железный черешковый наконечник стрелы типа «площик» с опущенными концами, бронзовую трехрогую лунницу. Если бы не стратиграфическое положение, склеп можно было бы отнести к более раннему времени. Но он перекрывает грунтовую могилу с конскими захоронениями. В этой могиле найдены железные удила с серебряными кольчатыми псалиями конца IV - первой половины V вв. Они и определяют дату могилы с конскими захоронениями. Она же ограничивает нижнюю дату склепа - V в. Этой дате не противоречат другие материалы, относящиеся к склепу. При этом надо иметь в виду, что склеп разграблен и в нашем распоряжении имеется не полный комплекс инвентаря. Следовательно, рубежи верхней даты склепа лучше не ограничивать.

Еще раз напомним, что грунтовая могила с погребениями животных, как уже отмечалось, датируется по железным удилам с кольчатыми серебряными псалиями V в., точнее, его первой половиной.

В грунтовой могиле с женским захоронением обнаружены браслеты и зеркало V-VII вв., застежка, аналогичная выявленной в погребении № 40 Верхнечирюртовского грунтового могильника сер. VII - второй половины VII вв. н.э. (Путинцева Н.Д., 1961. С. 257. Рис. 9, 4). Это позволяет определить дату этой могилы в пределах V-VII вв.

Таким образом, выявленные комплексы Курклинского могильника могут быть датированы в пределах V-VII вв. н.э.

Судя по характеру погребальных сооружений, погребального обряда и массового инвентаря, особенно, керамики, памятник имеет глубокие местные генетические корни и может быть охарактеризован как памятник местной раннесредневековой культуры. Вместе с тем находки изделий, характерных для обширной территории Северного Кавказа и Юго-Восточной Европы позволяют рассмотреть его как памятник, входящий в сферу культурного влияния гуннских и сармато-аланских племен. Кинжаловидный наконечник копья, плоские рамовидные пряжки и другие находки определяют своеобразие культуры исследованного нами памятника.

Дальнейшие раскопки этого интереснейшего памятника культуры племен Дагестана раннесредневекового времени дали бы многое для исследования культурно-исторической и этнической истории племен долины Казикумухского Койсу Дагестана. 


\section{БИБЛИОГРАФИЯ}

Абрамова М.П., 1977. Большой Буйнакский курган // Археологические памятники раннесредневекового Дагестана. Махачкала.

Абрамова М.П., 1980. Буйнакский курган // Древние и средневековые археологические памятники Дагестана. Махачкала.

Абрамова М.П., 1998. О датировке некоторых лунниц с территории Дагестана. // Древности Северного Кавказа. Махачкала.

Амброз А.К., 1989. Хронология древностей Северного Кавказа. М.

Атаев Д.М., 1963. Нагорный Дагестан в раннем средневековье (по материалам археологических раскопок Аварии). Махачкала.

Багаев М.X., 2008. Культура Горной Чечни и Дагестана. IV в. до н.э. - XII в. н.э. М.

Давудов О.М., 1996. Материальная культура Дагестана албанского времени.Махачкала.

Давудов О.М., 1977. Сумбатлинский могильник // Древние памятники Северо-Восточного Кавказа. Махачкала. 158.

Дмитриев А.В., 1979. Могильник эпохи переселения народов на р. Дюрсо // КСИА. М. Вып.

Дмитриев А.В., 1979а. Погребения всадников и боевых коней в могильнике эпохи переселения народов на р. Дюрсо близ Новороссийска // СА. № 4.

Засеикая И.П., 1979. Боспорские склепы гуннской эпохи как хронологический эталон для датировки памятников восточноевропейских степей // КСИААНСССР.М.Вып. 158.

Засеикая И.П., 1994. Культура кочевников южнорусских степей в гуннскую эпоху (конец IV V вв.). Санкт-Петербург.

Каргапольщев С.Ю., Бажан И.А., 1993. К вопросу об эволюции трехрогих пельтовидных лунницу в Европе(III-IV вв.) // Петербургский археологический вестник. СПб. Вып. 7.

Ковалевская В.Б., 1979. Поясные наборы Евразии IV-IX вв. Пряжки // САИ. Вып. Е1-2. М.

Котович В.Г., 1961. Археологические работы в Горном Дагестане // МАД. МАД. II. Махачкала.

Котович В.Г., Мунчаев Р.М, Путинцева Н.Д., 1961. Некоторые данные о средневековых памятниках Горного Дагестана // МАД. II. Махачкала.

Кропоткин В.В., 1978. Черняховская культура и Северное Причерноморье // Проблемы советской археологии. М.

Круглов А.П., 1946. Культовые места Горного Дагестана // КСИИМК. М. Вып. 12.

Кузнецов В.А., 1961. Аланские племена Северного Кавказа // МИА. 106, М, 1962.

Путинщева Н.Д., 1961. Верхнечирюртовский могильник (предварительное сообщение) // МАД. ІІ. Махачкала.

Смирнов К.Ф., 1952. Археологические исследования в Дагестане в 1948 - 1950 годах //

КСИИМК. XLV.

Смирнов К.Ф., 1961. Грунтовые могильники албано-сараматского времени у сел. Карабудахкент // МАД. ІІ. Махачкала.

Спицын А.А., 1905. Вещи с инкрустацией из Керченских катакомб 1904 г. // ИАК. СПб. Вып. 17.

Уварова П.С., 1900. Могильники Северного Кавказа // МАК. VIII. М.

Шкорпил B., 1910. Заметка о рельефе на памятнике с надписью Евпатория // МАК. 37. СПб.

Шкорпил В.В., 1907. Отчёт о раскопках в г. Керчи в 1904 г. // ИАК. СПб. Вып. 25.

Zakharov A.A., 1931. Contributions to Caucasian. Archacolody // ESA. V. 


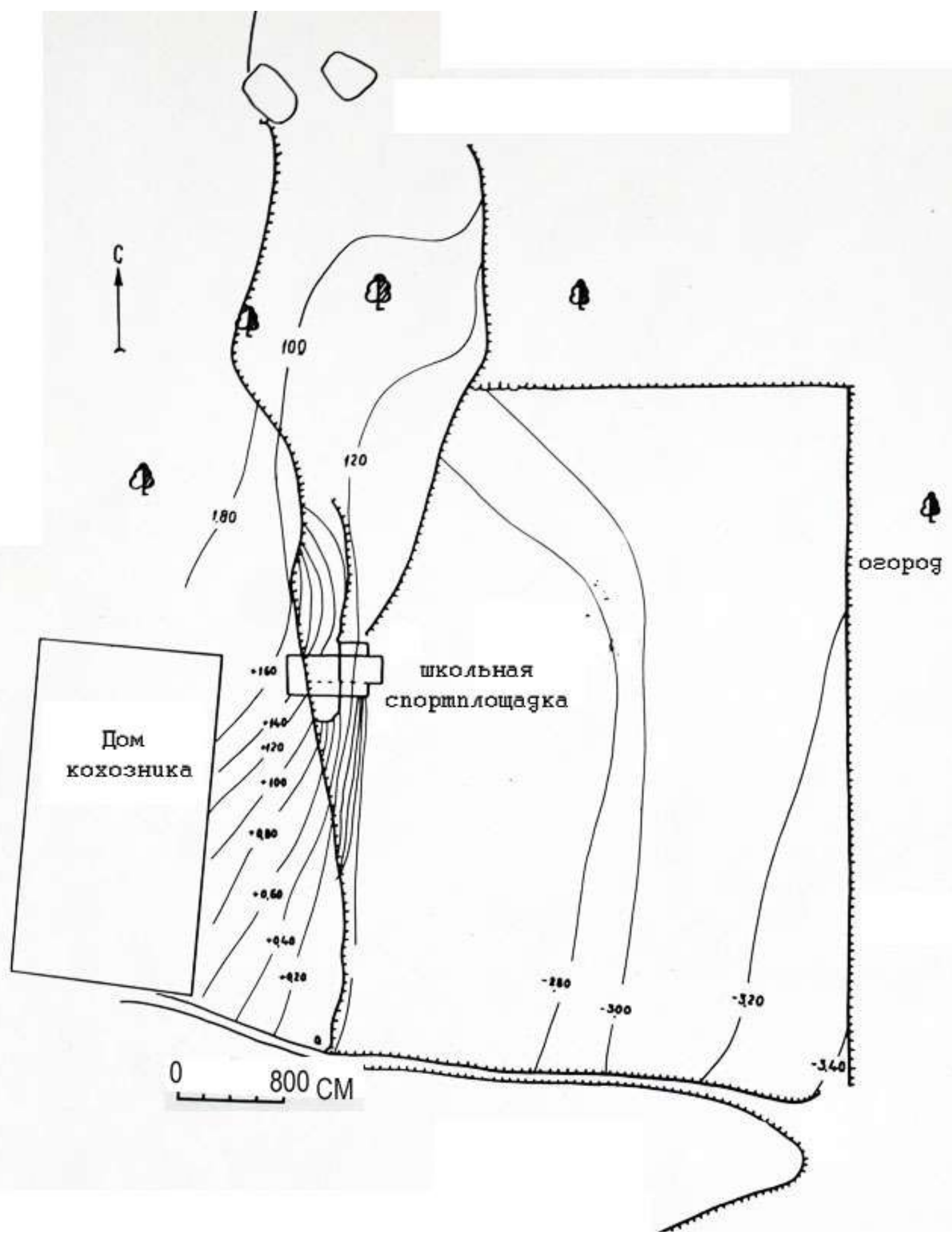

Рис. 1. План Курклинского могильника. 


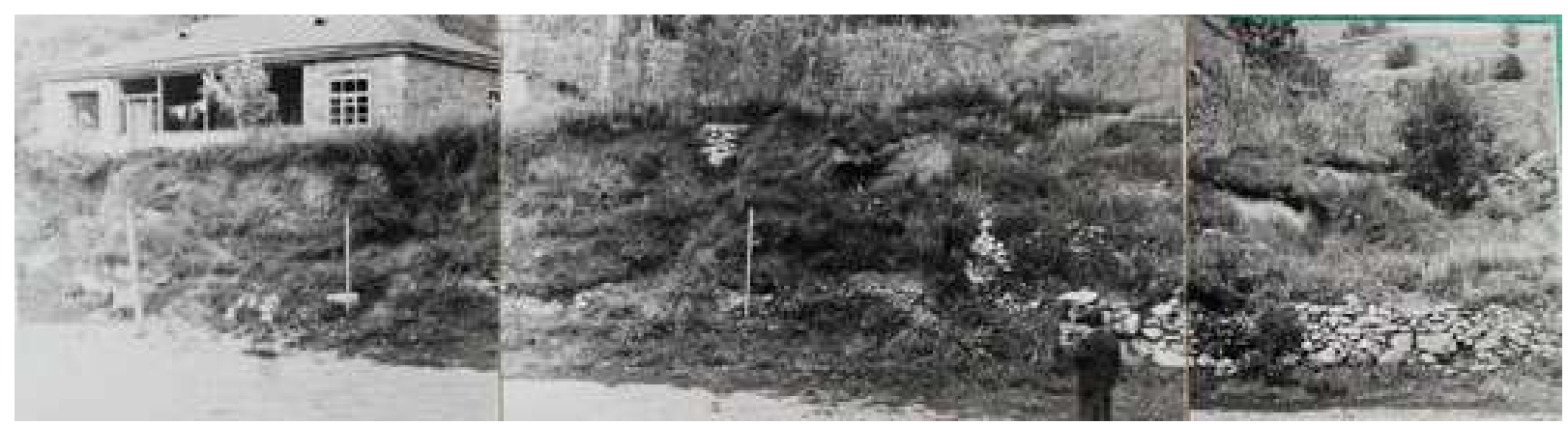

Рис. 2. Фото Курклинского могильника. Вид с востока.

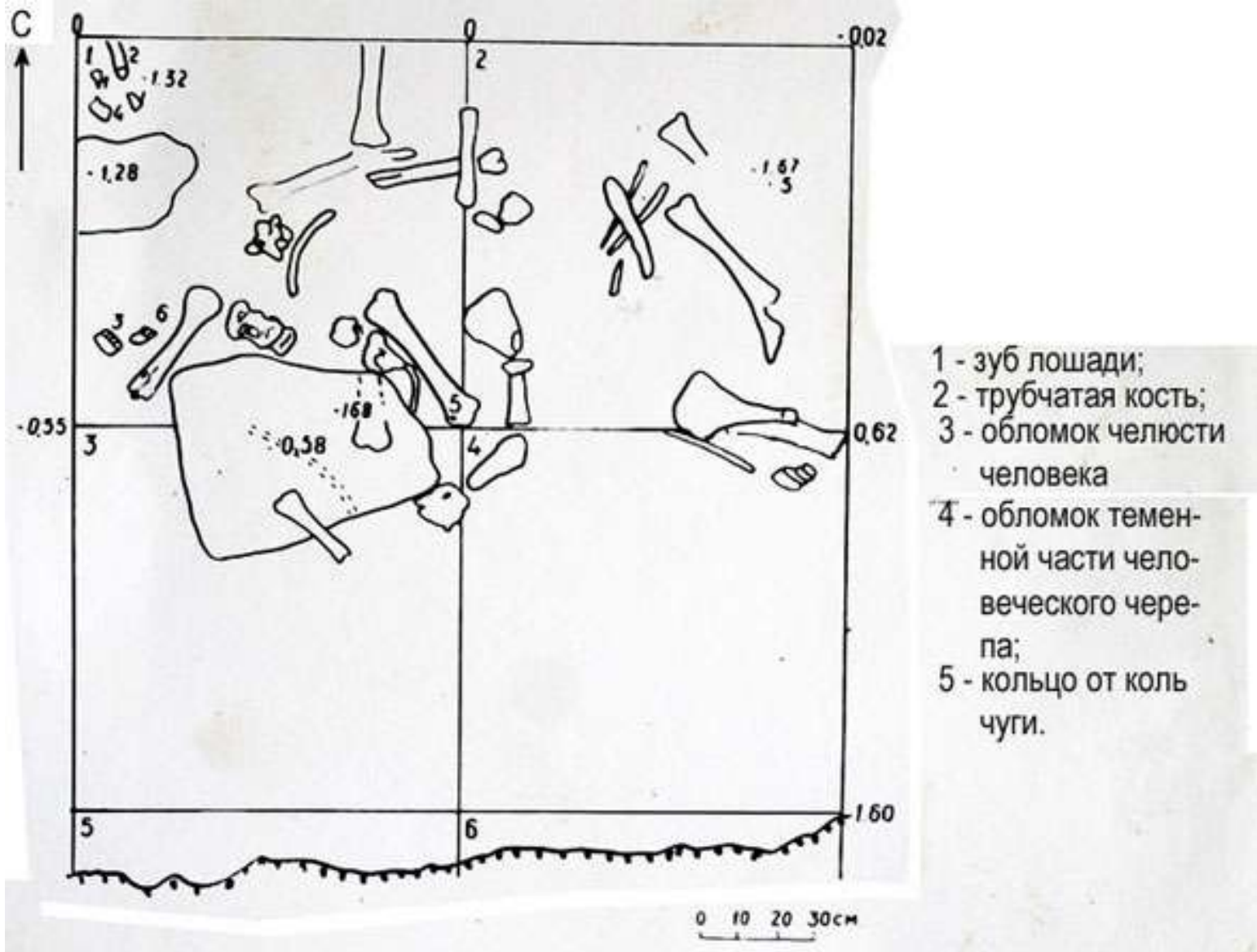

Рис. 3. План раскопа Курклинского могильника. На начальном этапе раскопок. 


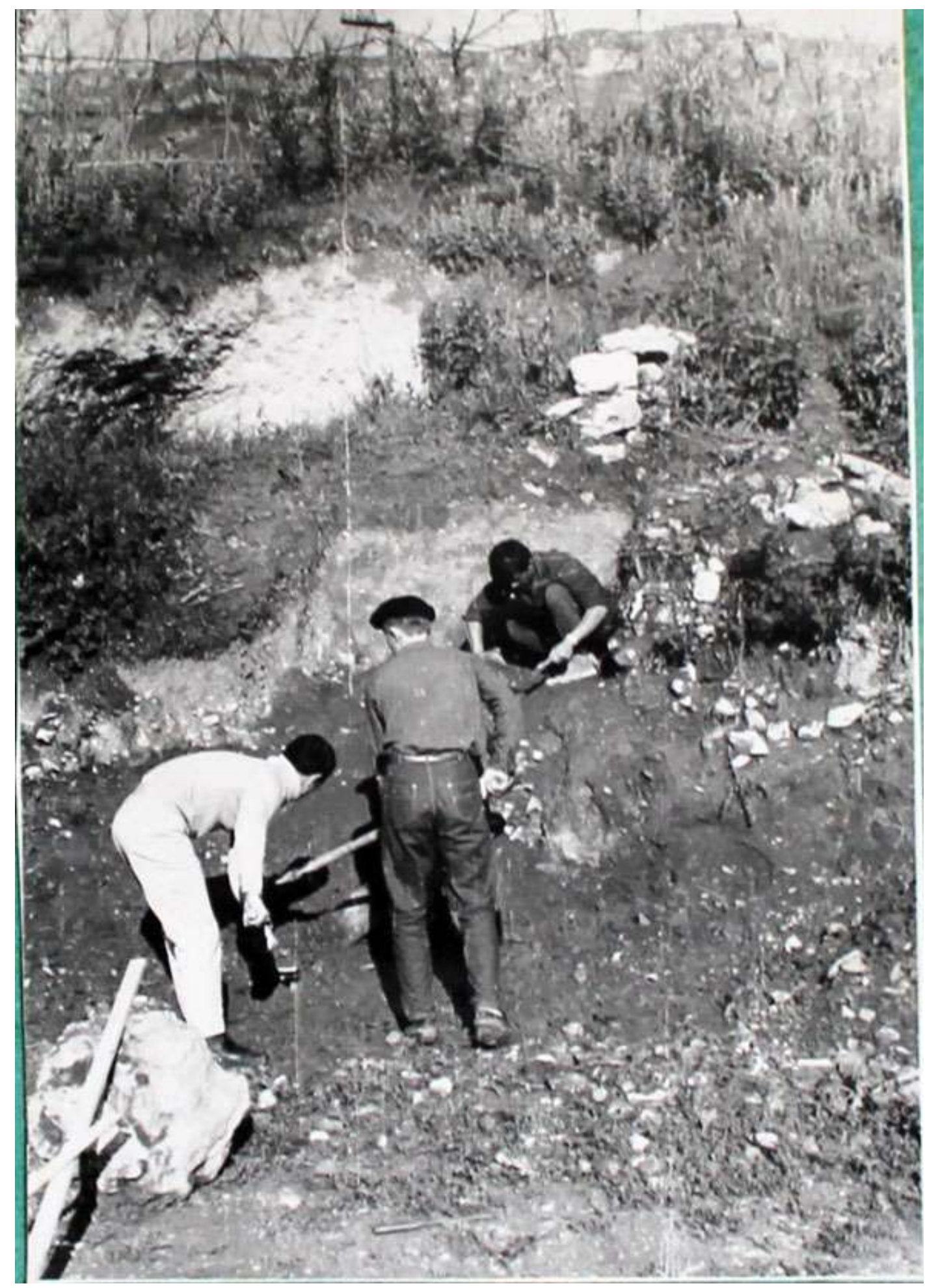

Рис. 4. Раскопки на могильнике. Рабочий момент. 


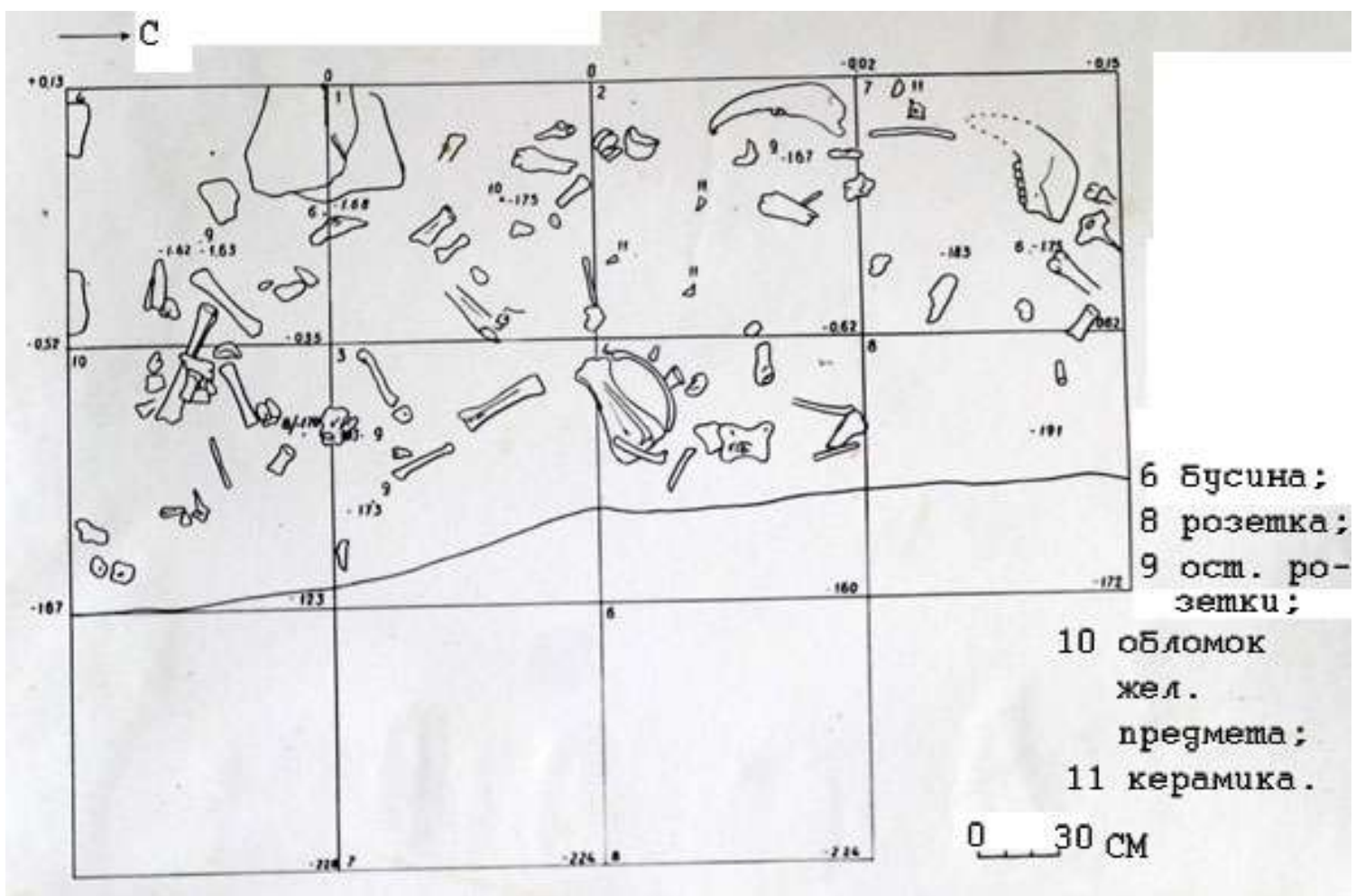

Рис. 5. План раскопа после прирезки.

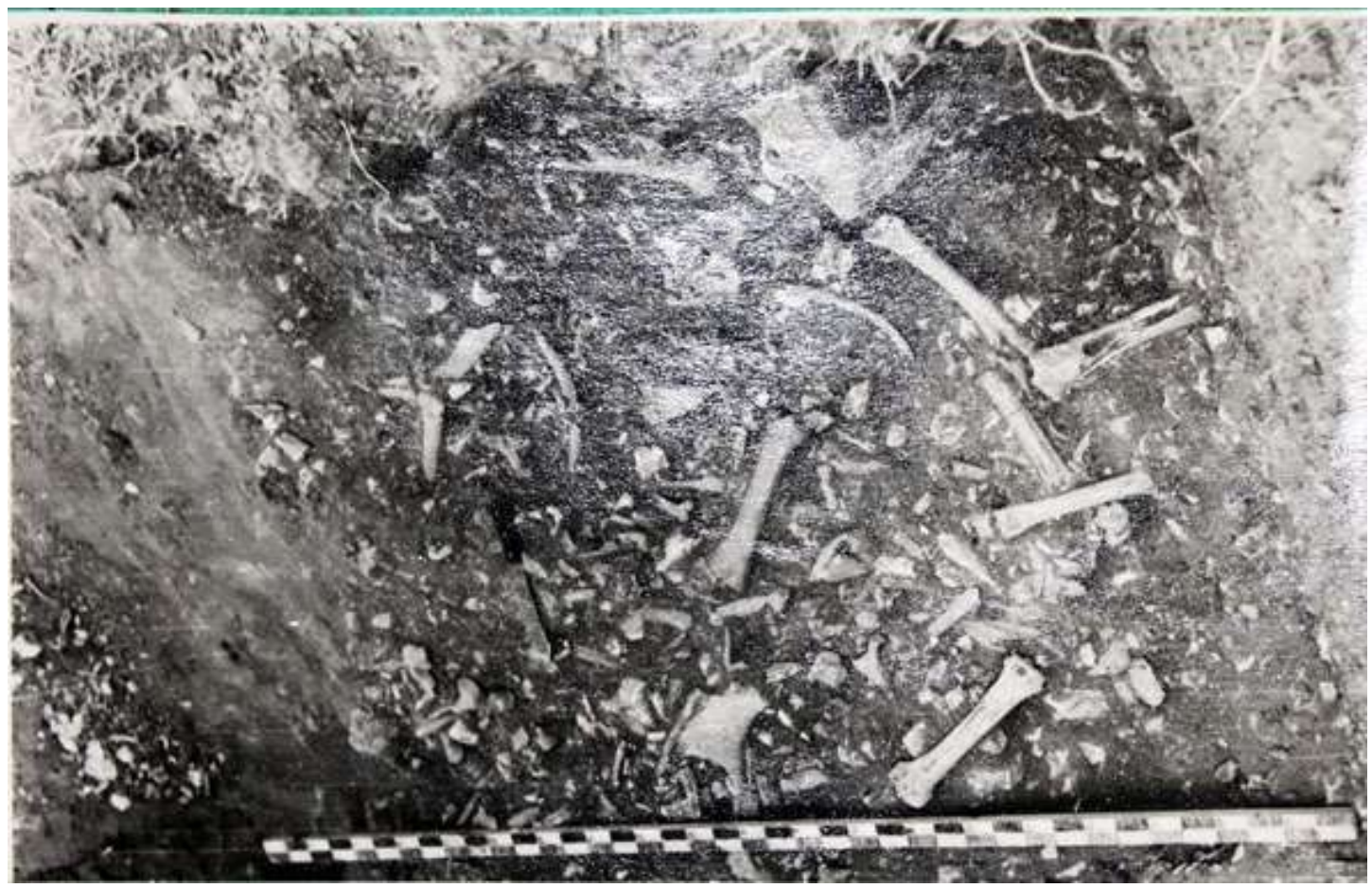

Рис. 6. Картина разрушенного погребального сооружения. 


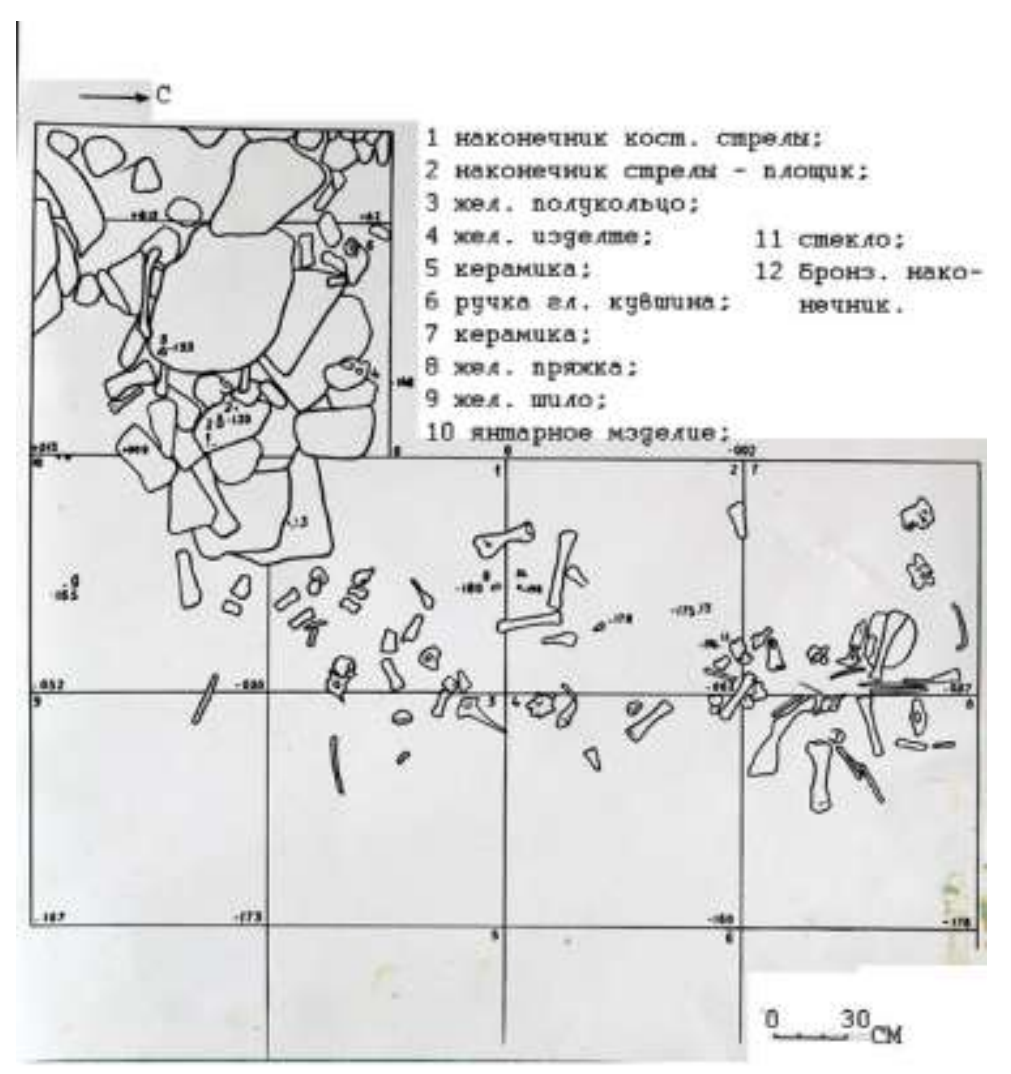

Рис. 7. План раскопа Курклинского могильника после очередной прирезки.

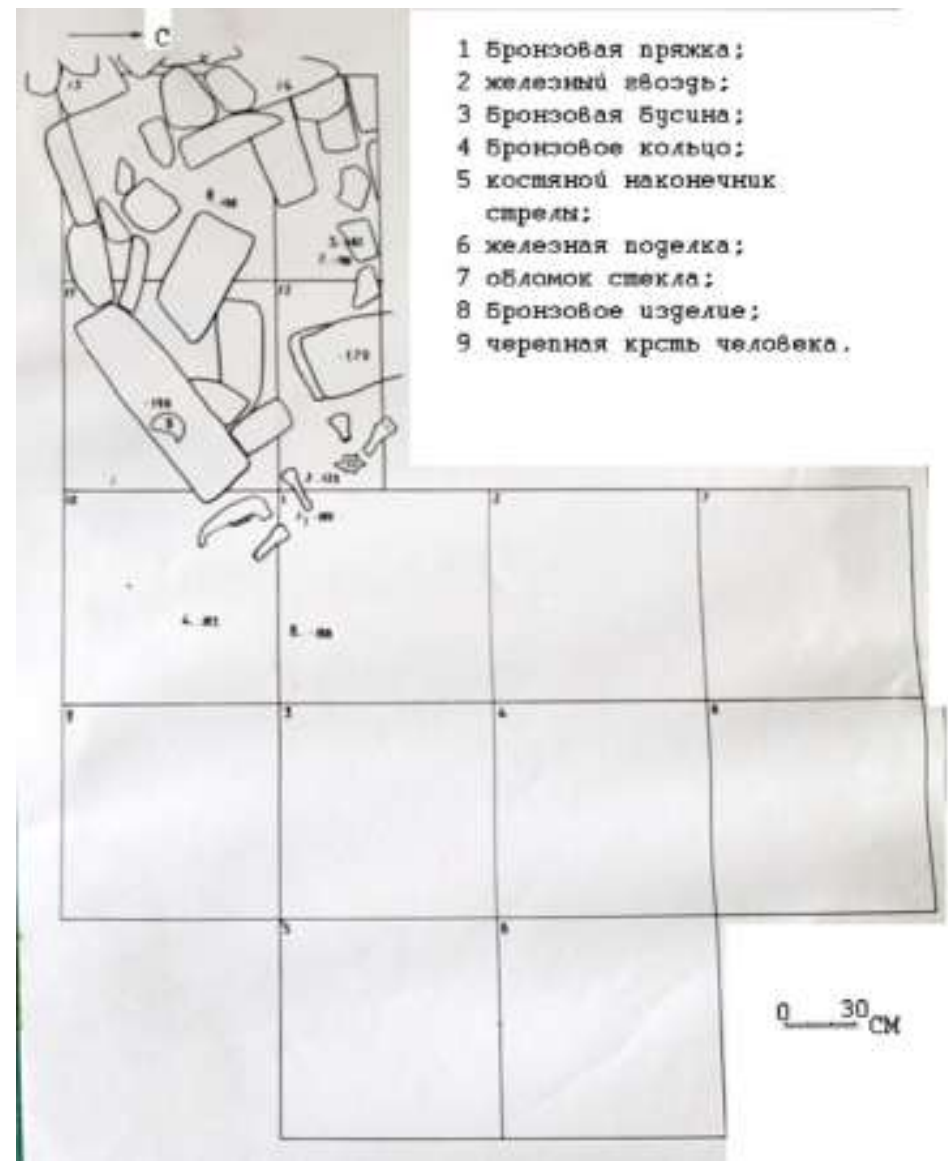

Рис. 8. План раскопа после углубления.

Проявляются очертания склепа. 


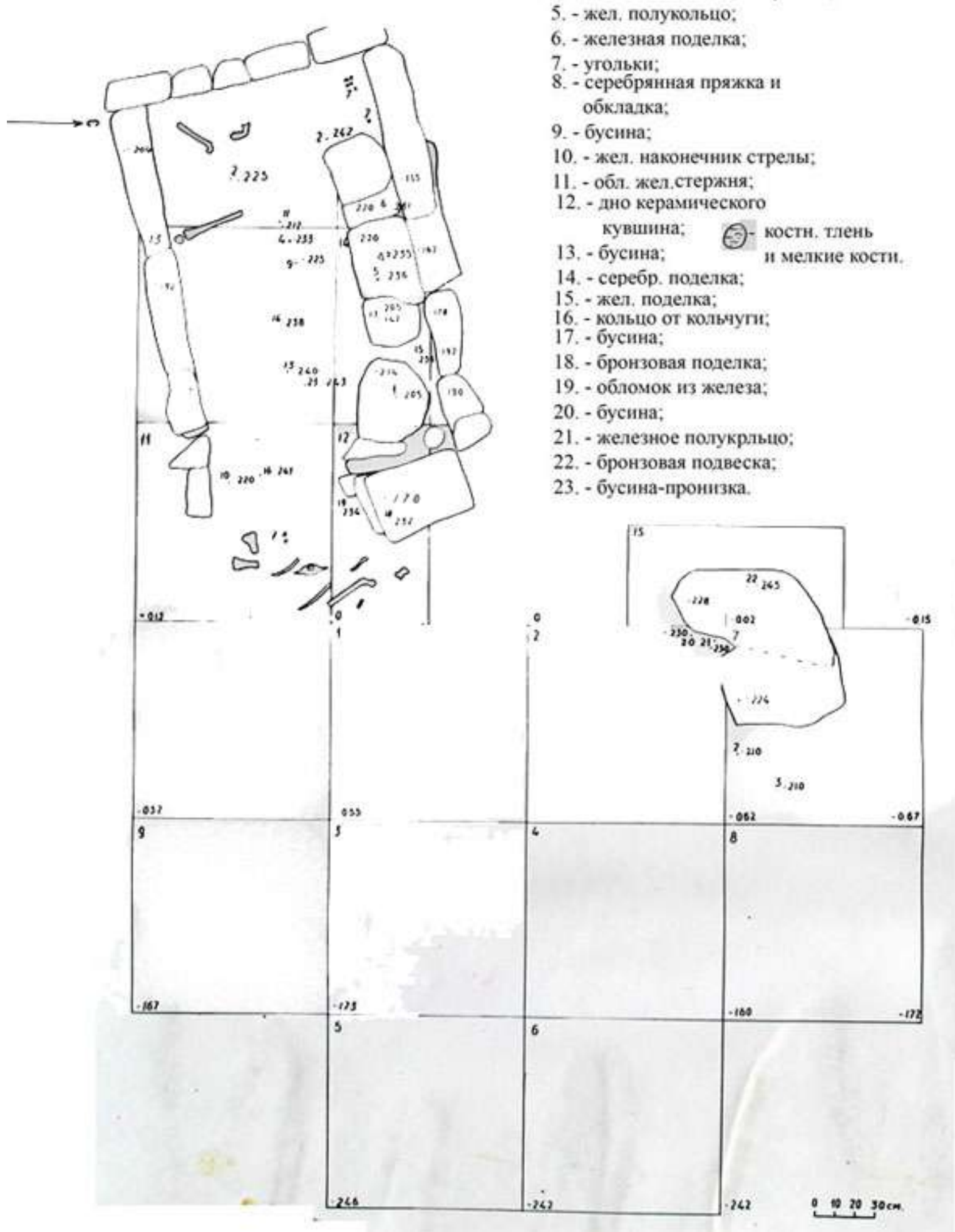

1. обломок бусины;

2. остаток кольчуги;

3 - жлезное полукольцо:

4. - деталь от железной пряжки:

5. - жел, полукольцо:

- железная поделка;

сереорянная пряжка

11. - обл. жел стержня

2. - дно керамического кувшина н мелкие кости.

16. - кольцо от кольчупи

22. - бронзовая подвеска

23. - бусина-пронизка

Рис. 9. План раскопа после расчистки.

Проявились очертания склепа и грунтовой могилы. 

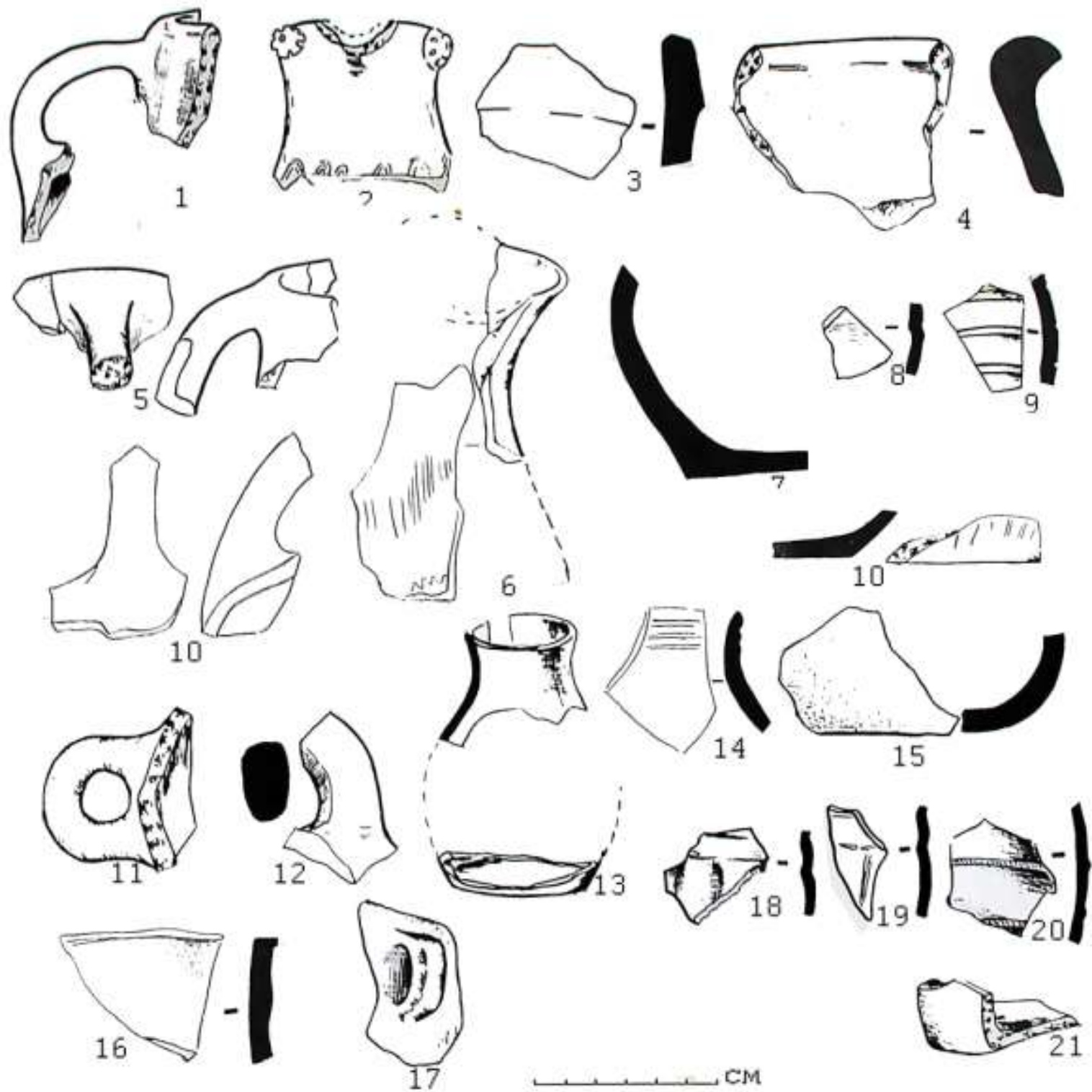

Рис. 10. Обломки керамических сосудов из склепа и прилегающей территории. 

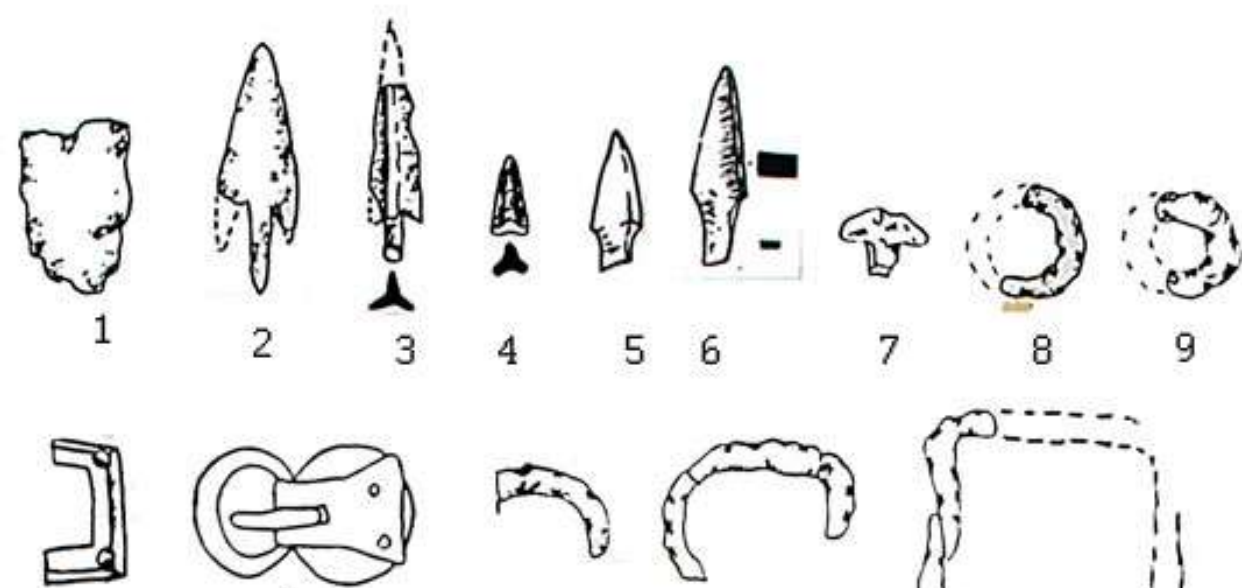

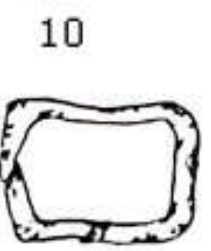

15

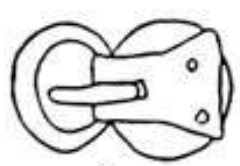

11
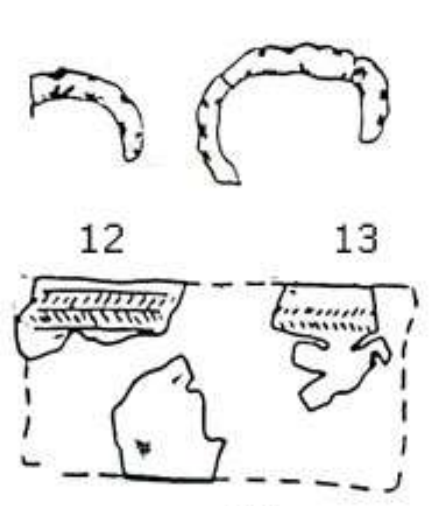

17

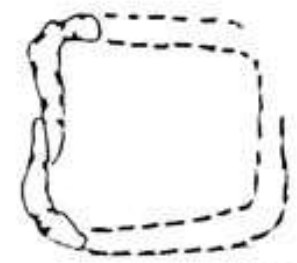

14

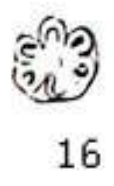

6
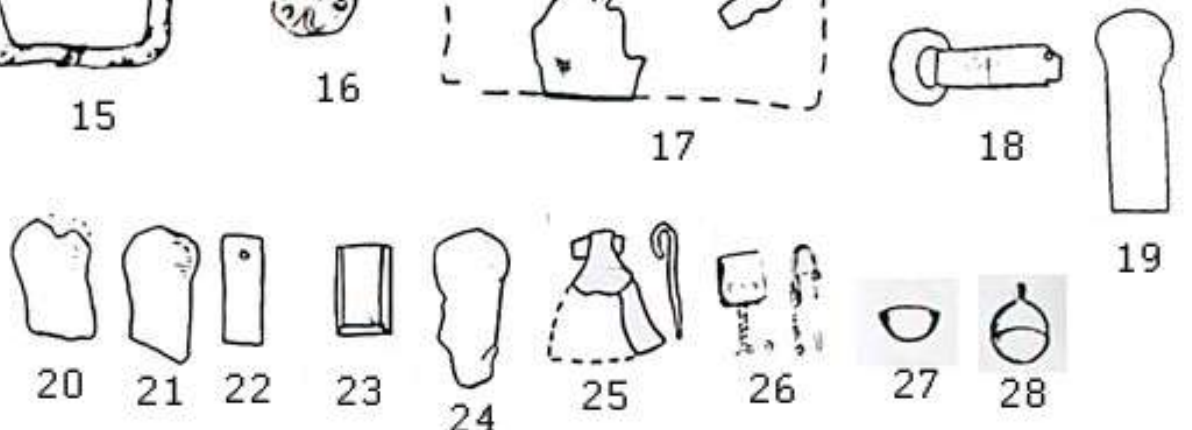

19

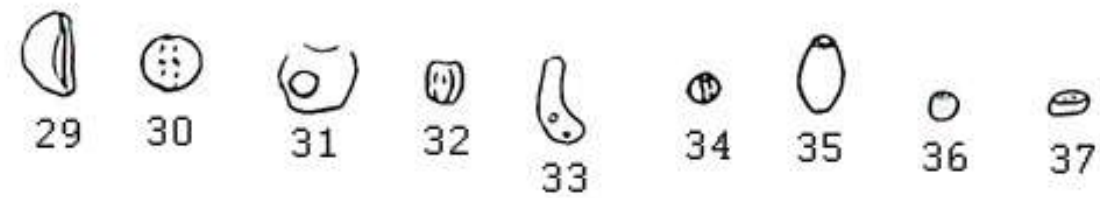

0 \& 8 (न)

$\begin{array}{lllll}38 & 39 & 40 & 41 & 42\end{array}$

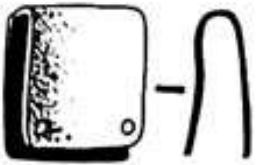

43

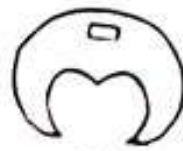

44

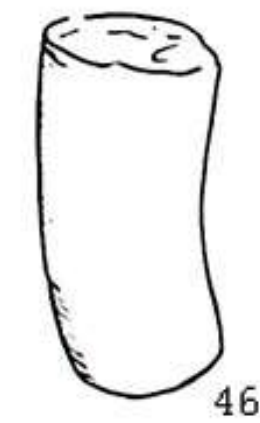

Рис. 11. Находки из склепа и прилегающей площади. 1, 2, 3, 4, 7 - 9, 12 - 15 - железо; $5,6,33$ - кость; $11,12,17,26,28,43,44$ - бронза; 16 - золотая фольга; 18 - 21, 24, 25 - серебро; керамика - 46. 


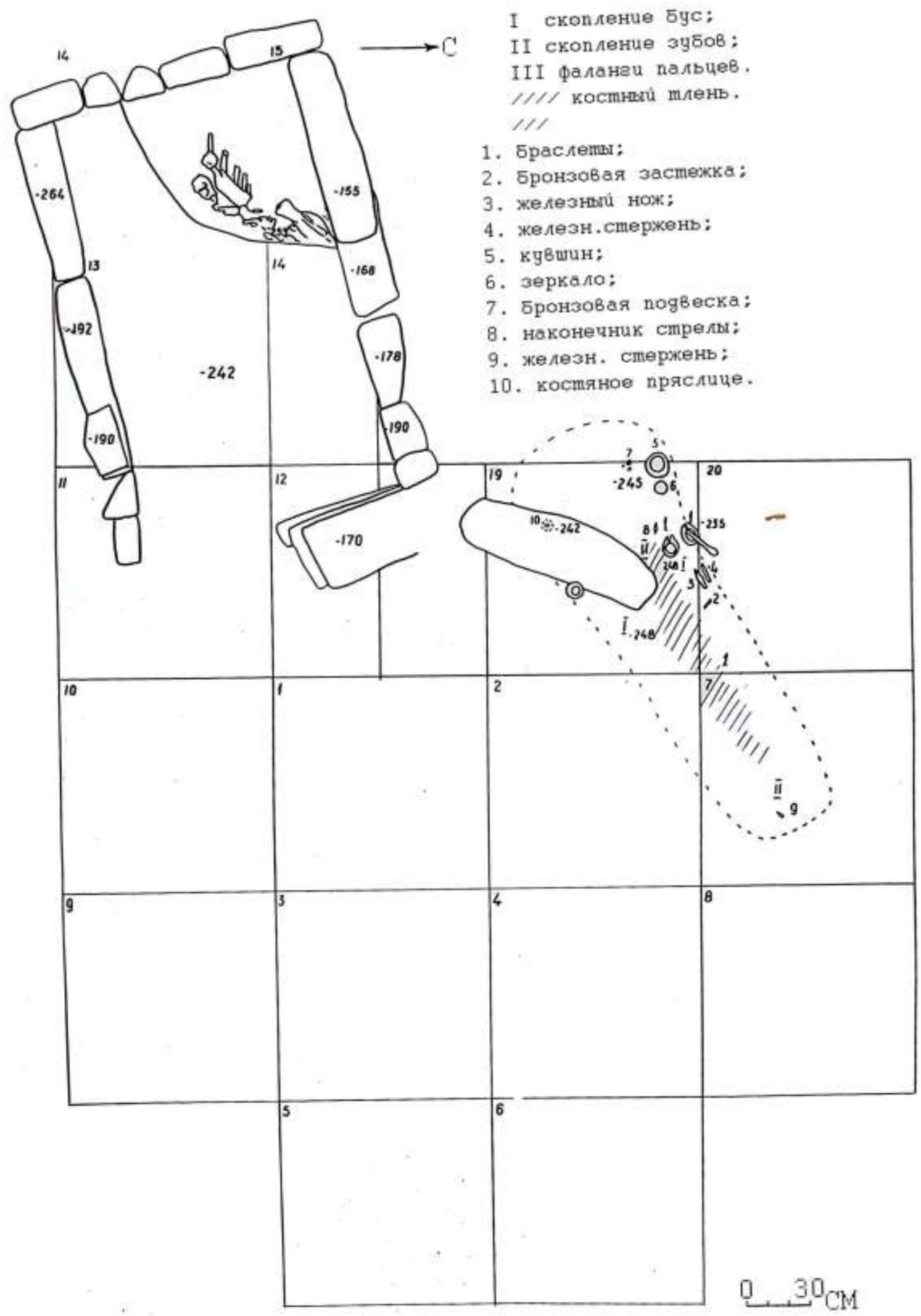

Рис. 12. Окончательный план раскопа.

Видны склеп с залегающей под ним грунтовой могилой с конскими захоронениями и грунтовая могила с погребением женщины. 

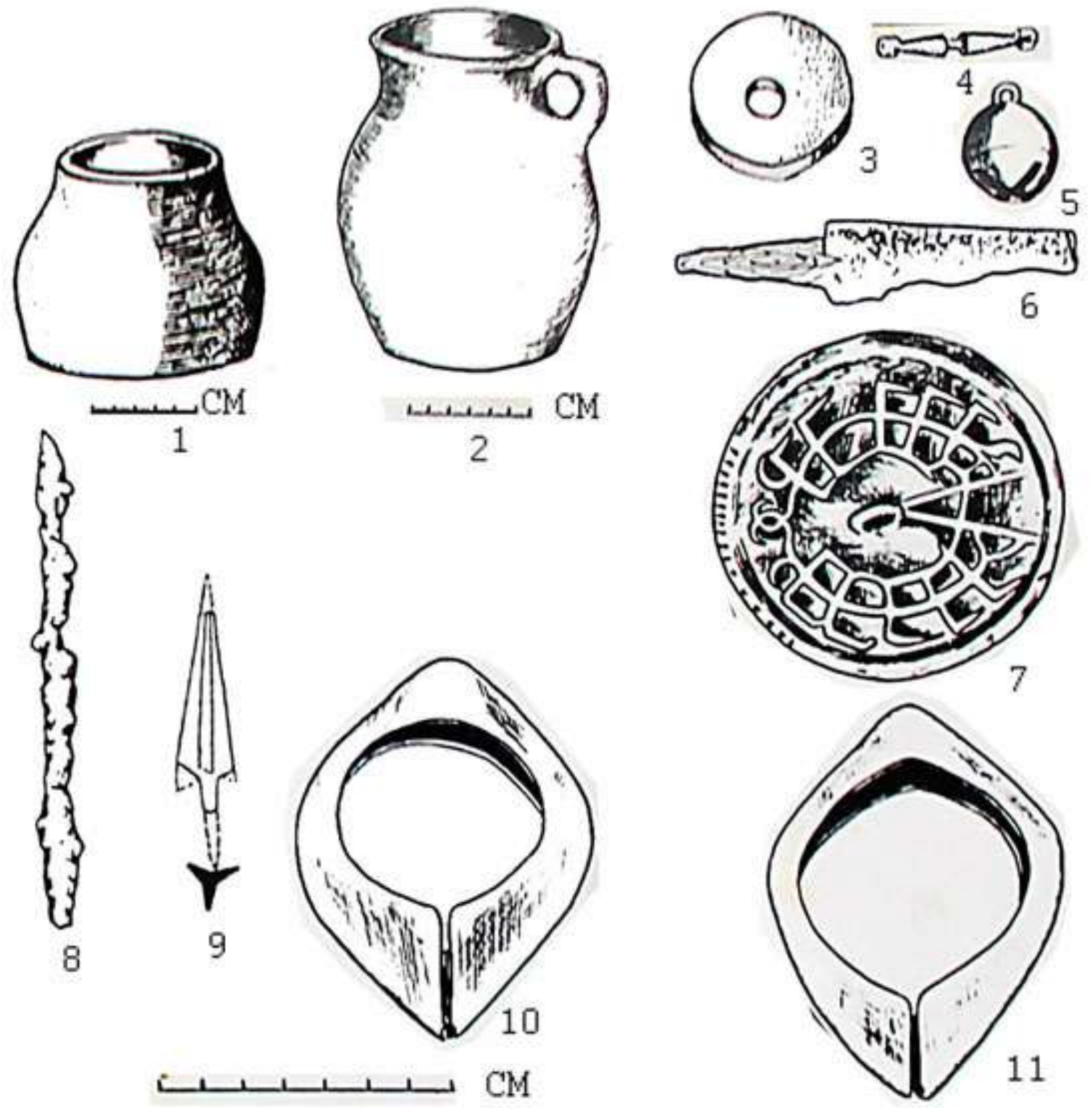

Рис. 13. Инвентарь из грунтовой могилы с захоронением жен щины. 1,2, 3 - керамика; 4, 5, 10, 11 - бронза; 6, 8, 9 - железо; 7 - биллон. 


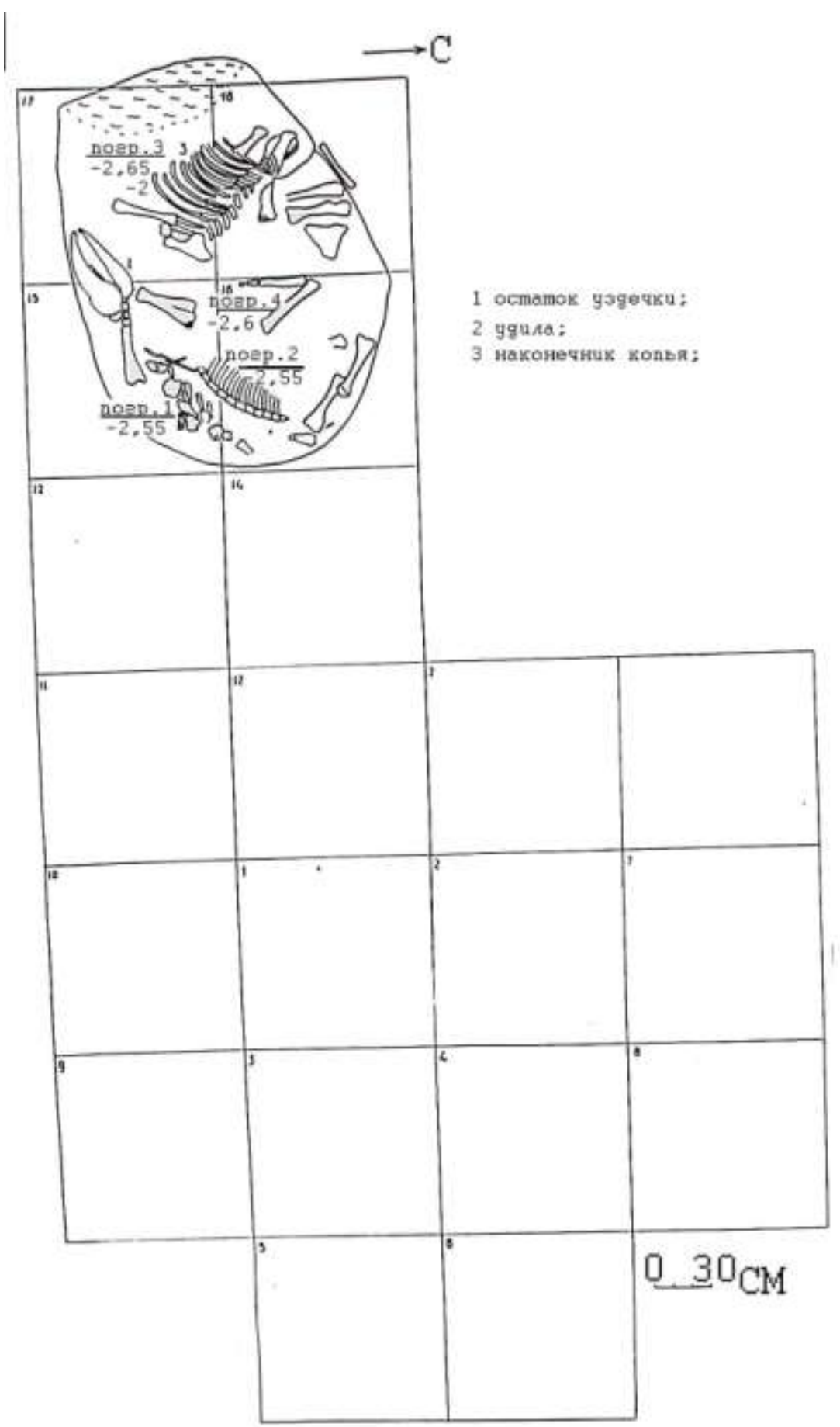

Рис. 14. План грунтового погребения с конскими захоронениями.

Верхний слой. 

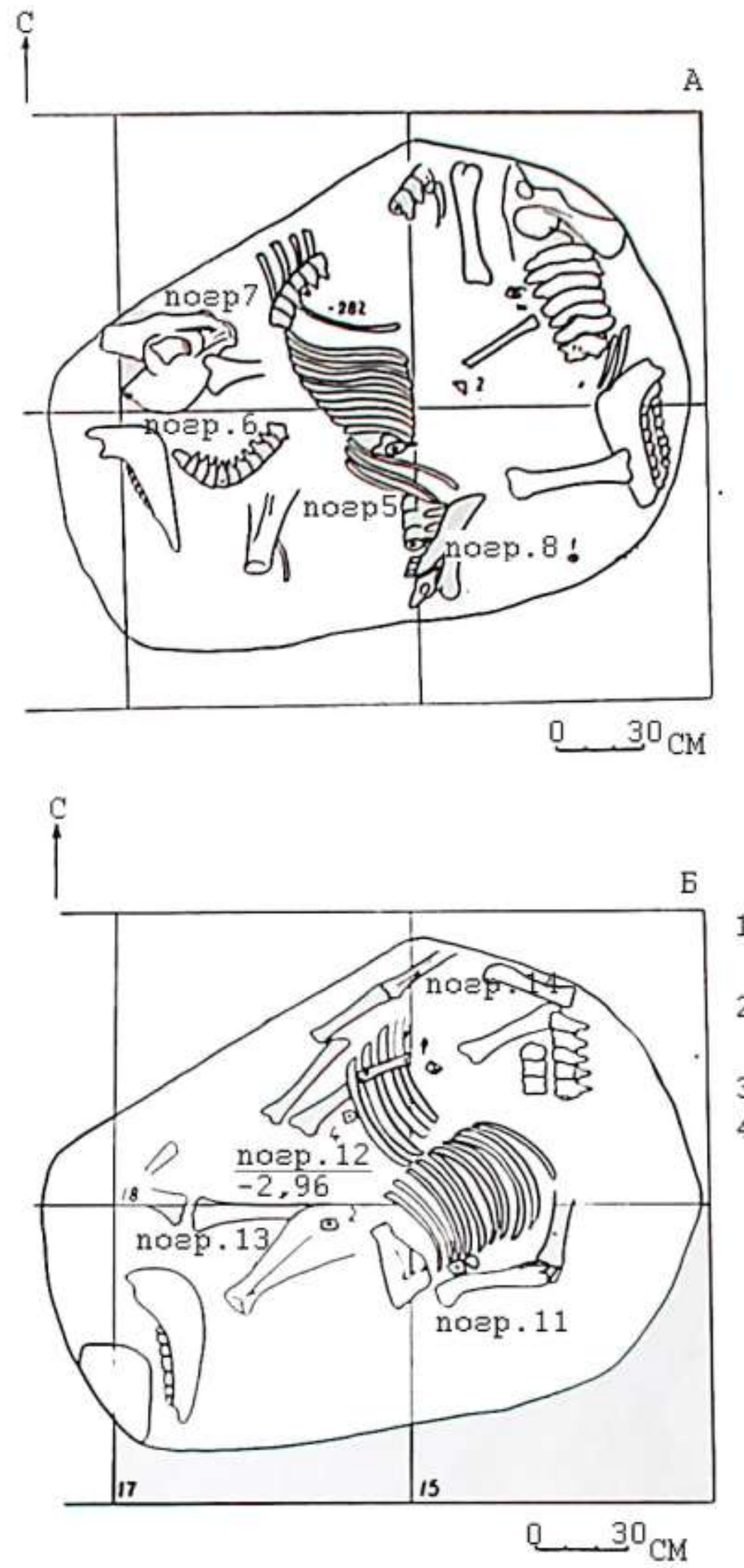

1 скопление пряжек ;

2 бронзовая пряжка ;

3 пряжка;

4 пряжка nлоская.

Рис. 15. Планы грунтовой могилы с конскими захоронениями. Второй (А) и третий (Б) слои. 


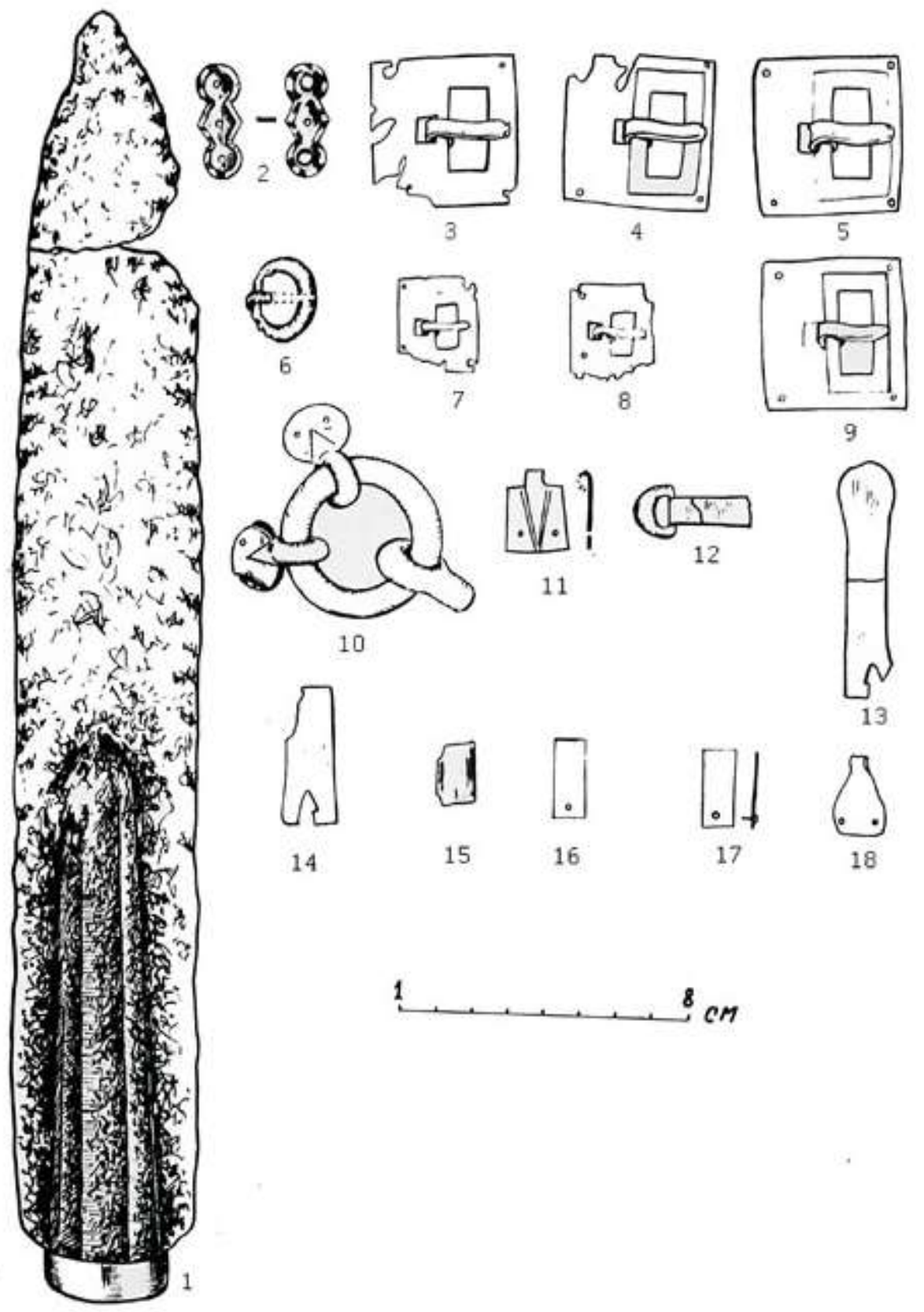

Рис. 16. Инвентарь из грунтовой могилы с конскими захоронениями. 1 - железо; 2, 10 - 18 - серебро; 3, 4, 5, 6, 7, 8, 9-бронза. 